Board of Governors of the Federal Reserve System

International Finance Discussion Papers

Number 513

June 1995

\title{
BANK LENDING AND ECONOMIC ACTIVITY IN JAPAN: \\ DID "FINANCIAL FACTORS" CONTRIBUTE TO THE RECENT DOWNTURN?
}

Allan D. Brunner and Steven B. Kamin

NOTE: International Finance Discussion Papers are preliminary materials circulated to stimulate discussior and critical comment. References in publications to International Finance Discussion Papers (other than an acknowledgement that the writer had access to unpublished material) should be cleared with the author or authors. 


\begin{abstract}
In this paper, we examine the role of "financial factors" in Japan and attempt to gauge their recent impact on the Japanese economy. First, we find that proxies for financial factors enter significantly in behavioral equations for loan standards, loan demand and aggregate demand, although these proxies explain only a small amount of the variation in those variables. Second, there is some, albeit inconclusive, evidence that balance-sheet problems of households and firms contributed to Japan's recent recession. We find that exogenous declines in equity prices contributed significantly to the decline in loans and economic activity, although part of this influence appears to be operating through traditional wealth effects. In addition, loan demand shocks, which could reflect balance-sheet problems not captured by our model, account for much of the remainder of the shortfall in loans and some of the shortfall in economic activity. Finally, we also find some evidence that an exogenous contraction in loan supply, a "credit crunch," may have lowered output by a small degree, but only in the early phases of the recession.
\end{abstract}




\title{
Bank Lending and Economic Activity in Japan: \\ Did "Financial Factors" Contribute to the Recent Downturn?
}

\author{
Allan D. Brunner and Steven B. Kamin ${ }^{1}$
}

\section{Introduction}

For most traditional theories of economic fluctuations, the financial sector does not play any relevant role. In the past few years, however, there has been renewed interest in developing theoretical models that emphasize the role of the financial system in generating or in propagating macroeconomic shocks. ${ }^{2}$ The basic premise of this research is that intermediated sources of credit are not perfect substitutes for other sources and that disruptions in the availability of intermediated credit have important real effects. These "financial factors" models typically rely on informational asymmetries between lenders and borrowers to motivate the special nature of bank credit. As a consequence of these asyrnmetries, borrowers are required to pay a premium for intermediated credit, and banks use a number of financial constraints or loan-qualification standards -- often linked to income, wealth or the ability to provide collateral -- to manage their expected costs of intermediation.

Then, as these arguments go, any adverse economic or financial shock that increases the expected costs of intermediation or reduces the income, wealth, or collateral values of borrowers will have nontraditional effects on the quantity of loans and on real economic activity. For example, banks may increase their loan rates and tighten their loan standards in the face of weaker balance-sheet positions of borrowers or in response to balance-sheet difficulties of their own. Even without tighter

1 The authors are, respectively, Economist and Senior Economist in the Division of International Finance, Board of Governors of the Federal Reserve System. The authors are grateful to John Ammer, Fobert Dekle, Allen Frankel, Diana Hancock, Dale Henderson, Paul Morgan, Larry Promisel, and Ted Truman for helpful comments and suggestions on earlier versions of this paper. They are also thankful to Al Teplin for his invaluable help in providing U.S. financial data and Betsey Stevenson for excellent research assistance. The views expressed in this paper are the authors and do not necessarily reflect those held by the Board of Governors or any member of its staff. The authors are responsible for any and all errors.

2 See Gertler (1988), Bernanke (1993), Gilchrist, Bernanke, and Gertler (1994), and Sharpe (1995) for recent surveys of the theoretical and empirical literatures. 
supply conditions, however, borrowers may become unqualified for loans if existing constraints become binding as a result of adverse shocks. In any case, borrowers are forced to pay inore for bank loans and some may be denied credit, just as the availability of other funds (such as income or wealth) is reduced.

There has also been a great deal of interest in testing the empirical importance of financial factors in explaining U.S. economic fluctuations. First, a number of studies have provided indirect evidence that for certain classes of borrowers bank loans are not perfect substitutes for other sources of credit. In particular, these studies indicate that "bank-dependent" firms are more sensitive to economic shocks than other classes of firms; see Gilchrist, Bernanke and Gertler for a recent survey of these studies.

Second, there is evidence that financial factors play a role in generating or amplifying U.S. economic fluctuations, although there is a great deal of question as to whether these effects are truly exogenous. On the credit demand side, Fazzari, Hubbard, and Petersen (1988) among others have found that deteriorations in firm balance sheets lead to reduced access to bank loans and reduced investment. Similarly, Mishkin $(1977,1978)$ found that the condition of household balanie sheets has implications for consumer spending. On the credit supply side, Bernanke (1983) has argued that asset price deflation in the Great Depression led banks to sharply reduce credit, reducing both aggregate supply and demand. Bernanke and Blinder (1992) found that monetary policy shocks lead to contractions in bank liabilities and economic activity. Similarly, Gertler and Gilchrist (1992), Oliner and Rudebusch (1992), and Gilchrist, Bernanke and Gertler (1994) have found that bank-dependent firms are more adversely affected than other firms by changes in banks' terms of lending due to monetary policy shocks. Bernanke (1990) and Kuttner (1992) have found that exogenous lending shocks have sizeable effects on aggregate demand. Finally, Bernanke and Lown (1991), Prek and Rosengren (1992), Hancock and Wilcox (1993, 1995), and Hancock, Laing, and Wilcox (1995) have 
found sorne evidence that bank capital shortages constrained bank lending and may have contributed to the recent U.S. recession; see Sharpe (1995) for a critical review of bank capital shortage studies.

The financial-factor hypothesis also appears to have been adopted by Japanese economic officials to help explain the 1991-93 Japanese recession. In a December 1993 Bank of Japan (BOJ) monograph, BOJ Governor Yasushi Mieno cited balance-sheet problems stemming from a collapse in asset pricies as a major contributor (along with excess capacity and business pessimism) to Japan's economic downturn. While the evidence for the recent U.S. experience is somewhat tenuous, there are various aspects of Japan's recent economic history that point to the possibility that financial factors did play an irnportant role in Japan ${ }^{\natural} \mathrm{s}$ recent economic difficulties. First, balance sheet positions of firms and households deteriorated sharply in the early 1990 s. $^{3}$ During the so-called "bubble economy" period of the late 1980 s, as asset prices rose swiftly, households and firms substantially increased their levels of liabilities relative to income. Unfortunately, asset prices collapsed with unprecedented rapidity in the early 1990 s, reducing net wealth and leaving many investments unprofitable.

Second, Japanese banks also faced substantial balance-sheet problems in the early 1990s and, as a result, increased intermediation costs. Initially, banks' problems were the consequence of heavy lending during the bubble period and of the subsequent collapse of asset prices, which led to a severe deterioration in loan quality, particularly in the real estate sector. Moreover, bank capital deteriorated rapidly in the early 1990s -- since a large portion of Japanese bank capital is in the form of unrealized gains on equity -- just as banks were subjected to more restrictive international capital standards. More recently, loan problems have been compounded due to the recession-related difficulties of the banks' borrowers.

Finally, banks play a far greater role in the allocation of credit in Japan, as compared to the

3 Schinasi and Hargraves (1993) present a broad overview of recent balance-sheet developments throughout the world and their implications for economic activity. See also OECD (1993a). 
U.S. and many other industrialized countries. As a result, it may be easier to identify the effects of financial factors in Japan. On the other hand, as argued by Hoshi, Kashyup, and Scharfstein (1991), the Japanese use of keiretsus (main bank relationships) may overcome informational asyınmetries, making financial factors in Japan less relevant.

The primary purpose of this paper is to take a closer look at financial factors in Japan and attempt to gauge their recent impact on the real economy. While the prima facie evidence cited above points to a possible link between financial distress and the recent downturn, the existence of this connection needs to be proven conclusively. Other factors, including the accumulation of excess capital stocks during the preceding "bubble economy" period and the continuing appreciation of the yen, may have been more important contributors to the economy's prolonged weakness. ${ }^{4}$

In our empirical work, we first estimate an econometric model of the Japanese economy that includes a role for "financial factors," similar to the approach suggested by Bernake and Blinder (1988). We then use the model to explore whether the recent collapse of bank lending and economic activity can be explained solely by traditional theories or, alternatively, whether the collapse can be traced in part to financial factors -- either because households and firms reduced their deniand for loans as a result of balance-sheet problems or because banks tightened the supply of bank loans in response to increased costs of financial intermediation.

Our results can be summarized as follows. We find that proxies for financial factors enter significantly in behavioral equations for loan standards, loan demand and aggregate demand, although these proxies explain only a small amount of the variation in those variables. Second, there is some evidence that balance-sheet problems of households and firms contributed to Japan's recent: recession, although this evidence is by no means conclusive. We find that exogenous declines in equity prices

4 Brunner and Kamin (1994) have summarized these more-traditional factors and have gauged their relative importance using an econometric model of the Japanese economy. 
contributed significantly to the decline in loans and economic activity, although part of this influence appears to be operating through traditional wealth effects. In addition, loan demand shocks, which could reflect balance-sheet problems not captured by our model, account for much of the remainder of the shortfall in loans and some of the shortfall in economic activity. Finally, we find some evidence that an exogenous contraction in loan supply (a "credit crunch") may have lowered output in the early phases of the recession, but had no discernable effect on economic activity later on in the downturn.

The paper is organized as follows. Section 11 reviews the channels thorough which financial factors can have real effects. Section III examines recent trends in balance-sheet conditions in Japan and the LI.S. Section IV describes our econometric model, while section V presents the results of using the model to determine the importance of financial factors in Japan's most recent economic downturn. Section Vl presents our conclusions.

\section{Financial Factors and Real Activity}

In this section, we outline several channels through which financial factors can affect real economic activity. In particular, assuming that intermediated credit (bank loans) is not a perfect substitute for other sources of credit, we discuss how adverse changes in economic or financial conditions: -- such as exogenous declines in asset prices or income or exogenous increases in interest rates or bank costs of intermediation -- can lead both to diminished loan demand and to constrained loan supply and, as a consequence, to reduced economic activity.

While the bank credit literature is quite voluminous and wide-ranging, it has generally emphasized two important characteristics concerning the role of bank loans -- that bank loans are not perfect substitutes for non-intermediated sources of credit (such as commercial paper, corporate bonds, or corporate equities) and that reductions in the access to bank loans or increases in the costs of bank credit result in diminished economic activity. Diamond (1984), Fama (1985), and Williamson (1986) were among the first to formally motivate the "specialness" of bank loans with the existence of 
informational asymmetries between borrowers and lenders. These asymmetries prevent lenders from directly observing characteristics of borrowers that determine the credit-worthiness of the borrower. ${ }^{5}$ Since these borrowers must be monitored, bank loan recipients pay a premium for intermediated credit. Moreover, borrowers are often subjected to various screening mechanisms -- such as the ability to provide collateral or the ability to meet certain income or wealth requirements -- in order to manage banks' expected costs of intermediation.

Assuming that bank credit is not a perfect substitute for other sources of credit, there are two basic channels through which changes in economic and financial conditions can affect the availability of bank loans and, consequently, the level of economic activity. First, adverse economic and financial shocks can lead borrowers to reduce their demands for credit beyond an amount that can be accounted for by traditional determinants loan demand, such as loan rates and aggregate economic activity. Firms and households may, for example, curtail their demand for loans due to increased expected costs associated with loan default or bankruptcy or due to the inability to initiate new spending or to qualify for bank credit as a result of cash flow or balance sheet difficulties. Second, adverse changes in economic and financial conditions may lead either to bank balance-sheet problems or to banks reassessing the riskiness of bank lending. In either case, the costs of intermediation increase, causing banks to restrict the availability of credit, either by increasing loan rates or by raising loan-qualification standards. These channels are discussed in more detail below.

Loan Demand Effects. In the traditional IS/LM framework, spending decisions of households and firms are assumed to be unrelated to financing decisions. However, if bank loans are not perfect substitutes for other types of credit as discussed previously, spending decisions will likely depend on the source and on the associated expected costs of borrowing. Even when cash-flow and balance-sheet

5 These characteristics include expected project return, amount of effort required by the borrowers for successful project completion, and intention on the part of the borrower to repay the loan. 
positions of firms and households are relatively strong, adverse changes in economic and financial condition; can affect the distribution and the expected marginal costs of borrowing. As discussed by Gertler (1988), Bernanke (1993), and Gilchrist, Bernanke, and Gertler (1994), such changes are likely to reduce firms' internal resources available for investment and force firms to seek more costly forms of externall finance, such as bank loans. Likewise, adverse changes may push households toward bank loans in an attempt to smooth consumption. Conversely, for risk-averse firms and households alike, reductions; in net wealth, in expected future earnings, or in collateral values may increase the probability of costly loan defaults or bankruptcy, which might lead to curtailed investment and consumption and, therefore, to feduced borrowing from banks.

If the adverse changes in economic or financial conditions are especially strong, they may have additional, more severe (nonlinear) effects on credit demands and economic activity. First, reductions in earnings or in asset values and associated asset income may impede the ability of firms and households to service existing debt. That is, some economic agents may become liquidityconstrained, which would tend to disrupt current consumption and the completion of current investment projects. Second, changes in economic and financial conditions may result in some household and firm borrowers becoming credit-constrained, as borrowers' net wealth, current income or available collateral no longer meet banks' loan-qualification standards. Finally, bad economic news may lead to actual loan defaults and bankruptcies, which are often associated with temporarily-idle resources and unproductive expenses (due, for example, to loan workout programs or legal proceedings).

Loan supply effects. The bank credit literature has also emphasized various loan supply effects of changes in economic and financial conditions due to the existence of financial factors. First, it is generally assumed that banks view their expected costs of monitoring borrowers as being correlated with certain economic and financial factors that indicate borrowers' ability to repay their loan obligations. In response to changes in these factors, banks are likely to tighten the supply of 
loans, either by raising loan rates or by raising long-qualification standards. Either of these actions will lead to reduced lending and, possibly, to lower spending by households and firms.

Second, with extreme unexpected changes in economic and financial conditions, additional, more severe (nonlinear) effects may result. For example, if large numbers of loan defaults occur, banks may become burdened with carrying large quantities of nonperforming loans (i.e., non-interest expenses), which tends to increase the costs of intermediation. Also, decreases in banks' net worth due to asset price declines or increases in regulatory capital requirements may restrict the ability of banks to extend credit, since capital-to-asset ratios and net worth are the primary determinants of banks' capacity and willingness to lend. Under any of these circumstances, banks may tighten the supply of credit, either through loan rate or loan standards. In that case, so-called "credit crunches" or "capital crunches" might lead to weaker aggregate economic activity. ${ }^{6}$

\section{Recent Trends in Balance-Sheet Indicators}

As we discussed in the previous section, the balance-sheet conditions of firms, households and banks provide a "litmus test" for the health of the credit allocation process. In this section, we attempt to gauge the impact of recent asset price declines on the balance-sheets of households, firms and banks in Japan. In order to provide some perspective, we compare various indicators of balance-sheet conditions to their historical values and to similar measures in the U.S. While these measures are highly aggregative and not strictly comparable across the two countries, their trends are indicative of the evolution of balance-sheet positions and whether changes are significant enough to have affected aggregate economic activity.

Households. Figure 1 compares several household financial indicators in Japan and the United

${ }^{6}$ See Bernanke and Lown (1991), Syron (1991), Peek and Rosengren (1992), Hancock and Wilcox (1993, 1995), and Hancock, Laing, and Wilcox (1995) for recent U.S. evidence of these effects. See also Sharpe (1995) for a critical review of these studies. 
States. The top panels present ratios of liabilities, assets and net worth (assets minus liabilities) to income. The panel for Japan makes clear that while the ratio of liabilities to income rose moderately throughout the 1980s, Japanese households accumulated assets at a much faster pace, leading to rapidly rising levels of net worth.

The acceleration of Japanese asset accumulation in the 1986-89 period corresponds to the socalled "asset bubble," when Japanese stock and land prices rose markedly. ${ }^{7}$ These increases were considerably steeper than those experienced in the United States, and the subsequent decline in asset prices wa:s steeper as well. While the collapse of the asset bubble substantially diminished the assets and net worth of Japanese households, however, the estimated value of Japanese net worth (as a ratio to disposable income) in 1993 still exceeded that in 1985 by over 10 percent. That is, the financial position of Japanese households was stronger in 1993 than at any time prior to the late 1980 s.

The middle panels of Figure 1 present an alternative measure of household solvency, the ratio of liabilities to assets. For a given level of net worth, a higher ratio of liabilities to assets places the householcl at greater financial risk, since there is a higher chance that unforseen developments -- say, a stock market crash -- could lower the value of a household's assets below the level of its liabilities, forcing it into bankruptcy. The tremendous rise in land and stock prices during the 1980s lowered Japanese liabilities-to-asset ratios considerably, while the subsequent crash raised them again. On net, however, the liabilities-to-assets ratio of Japanese households have risen only modestly above its average value during the first half of the 1980s. By contrast, the liabilities-to-assets ratio for U.S. householcls rose steadily from 1983 onward.

Finally, the bottom panels show the evolution of household interest payments in Japan and in the United States. The ratio of interest payments to income probably is the most direct measure of the

7 See: EPA (1993) for a comprehensive discussion of the asset bubble and its impact on household and corporate balance sheets. 
impact of financial developments on the cash flow position of households, and hence may be an important determinant of household spending decisions. As the data indicate, the burden of interest payments rose very gradually in Japan through most of the 1980s, rose more markedly in the 1989-91 period, when interest rates were raised substantially, but has since declined with subsequent declines in interest rates. By 1993, liabilities-service burdens for households were only marginally above their 1980 level. By comparison, household interest payments in the United States rose more swiftly and steadily in the $1980 \mathrm{~s}$, although most of this runup was reversed after interest rates began to decline in 1990.

In sum, even after the precipitous decline in asset prices, the financial position of Japanese households has not been severely compromised when compared to its pre-bubble level. .Japanese consumers may have cut back on recent spending in response to the swift reduction in their net wealth caused by the asset bubble. However, concerns about onerous liabilities-service burdens, excess indebtedness, and possible bankruptcy, which probably would have longer-lasting effects on household consumption, most likely have not been an important factor in depressing household sperding. This is consistent with the relatively scant attention paid in the Japanese financial press to consurner debt problems, contrasting with the strong concerns about household indebtedness, particularly credit card debt, that have been underscored in the U.S. financial press.

Firms. Figure 2 compares the evolution of corporate balance-sheet indicators in Japan to those in the United States in the past 1-1/2 decades. As shown in the top panels, liabilities-to-income ratios rose steadily throughout the 1980 s both in Japan and in the United States. However, in Japan, increased corporate indebtedness was more than matched by increased assets. These increasing asset levels only partially reflected rising stock and equity prices, so that even after the collapse of the asset bubble, corporate net worth ratios exceeded those in the mid-1980s. By comparison, assel-to-income ratios among U.S. firms actually declined over most of the period. As a result, levels of U.S. 
corporate net worth were significantly lower in the early 1990s than they were a decade earlier.

The different evolution of corporate balance sheets is even more apparent in the middle two panels of Figure 2. Ratios of liabilities to assets actually declined in Japan from 1985 to 1990, in part reflecting the special character of corporate financing during the bubble economy. Most large Japanese firms shifted from bank financing to either self-financing, equity-financing, or the capital markets during this period -- see Takeda and Turner (1992) and Fries (1993). As noted above, much of the proceeds of this financing was spent on land and equities which appreciated sharply at the end of the 1980 s. Both these factors tended to depress liabilities-to-asset ratios. The subsequent decline in asset values caused these ratios to rise again, but current liabilities-to-asset ratios are only moderately higher than those in the mid-1980s. By contrast, U.S. firms actively substituted debt for equity during the 1980 s, resulting in the steady increase in liabilities-to-asset ratios shown in the middle right-hand side panel of Figure $2 .^{8}$

Finally, the bottom panels compare trends in interest payment burdens for Japanese and U.S. firms. Notwithstanding steady, albeit small, increases in liabilities-to-income ratios from 1980 to 1989, Japanese interest payment burdens declined steadily over this period, reflecting sustained reductions; in loan interest rates. Starting in 1989, interest rates were raised substantially in an effort to forestall inflationary pressures associated with an overheating economy, thereby boosting the interest payment-to-income ratio for Japanese firms. Even so, this ratio rose only to its 1984 level, and remained below its value at the beginning of the decade. Hence, it is unlikely that the increase in the burden of interest payments was the primary factor underlying the collapse of business investment spending after 1991.

8 Acisording to the OECD (1993a, page 28), "In the United States the accumulation of gross debt was driven primarily by a switch in the debt-equity financing mix...In Japan the increase in corporate debt occurred as part of an overall balance-sheet expansion which involved substantial raisings of both debt and equity to finance asset acquisition...Throughout this period of financial expansion, Japanese corporations remained net issuers of equity, and debt/equity ratios did not rise." 
In sum, compared with the United States, where rising corporate indebtedness is believed to have contributed significantly to its recent recession, corporate balance-sheet indicators in Japan, at least for the corporate non-financial sector as a whole, appear to have deteriorated less sibstantially over the past decade. This suggests that corporate balance-sheet problems probably were not a major factor in Japan's recent downturn, and are unlikely to be a significant impediment to the on-going recovery as well.

While the financial condition of the non-financial corporate sector appears moderately healthy in aggregate, however, some sub-sectors certainly are suffering from balance-sheet problems. The real estate sector has experienced the strongest deterioration of its balance sheets. This reflects the fact, first, that it relied more heavily upon debt-financing than most other Japanese industries during the 1980s; between 1985 and 1990, outstanding real estate-related bank loans nearly doublecl, while loans to other sectors grew only 38 percent [Fries (1993)]. Secondly, the overbuilding during the bubble economy period, and associated collapse of real-estate values thereafter, hit the real estate sector especially hard. In consequence, ratios of debt to sales in the real estate sector rose 120 percent from 1985 to the first quarter of 1993. By comparison, the debt-to-sales ratio of all industries rose only about 40 percent, and that of manufacturing enterprises rose only 24 percent [EPA (1993)]. Partially as a result, the real estate's judgement of its financial position (Tankan survey) was surveyed at 0 (percent responding "easy" minus percent responding "tight") in August 1994 compared with 7 for the non-manufacturing sector and 8 for all industries [Bank of Japan (1994b)]. Nevertheless, it would be premature to conclude that balance-sheet problems in the real estate sector underlite the slump in construction and/or in private investment more generally. The depressed condition of the real estate industry probably owes more to the overhang of underutilized commercial real estate in Japan, as well as to the associated plunge in real estate prices. While the presence of excess capital stock in the form of empty buildings represents an asset imbalance of sorts, it is not the type of balance-sheet problem 
associated with excess indebtedness and diminished ability to repay.

Perhaps a more worrisome concentration of balance-sheet difficulties exists in the small- and medium-sized firm sector. In contrast to larger firms that tapped into buoyant equity and capital markets during the late 1980 s, smaller firms remained dependent upon bank financing for their capital expansion. In consequence, their debt-to-sales ratio rose by about 46 percent between 1985 and 1993, while that of large enterprises rose only about 34 percent [EPA (1993)]. Balance-sheet difficulties for smaller eriterprises potentially could weaken Japan's recovery, as investments by these firms are believed to have led investment by large firms after previous recessions [OECD (1993b)]. There is no strong evidence that rising indebtedness among smaller firms has made the recession longer or deeper to date, but there are signs of poor performance in this sector that could make future growth more sluggish than it might be otherwise. ${ }^{9}$

Banks. The counterpart of the reduced financial health of the real estate and small-firm sectors has been a marked deterioration of the balance-sheet positions of banks. Japanese banks were forced to increase substantially their exposure to those sectors, as larger Japanese firms increasingly looked elsewhere for financing in the late 1980s. As a result of high exposure to those sectors that were especially hit hard by the current downturn, an increasing share of the Japanese banking system's loans became non-performing.

Reported nonperforming loans for the eleven city banks rose from 3.1 percent of total loans in March 1993 to 3.3 percent in March 1994. Importantly, these percentages are understated relative to the U.S. definition of "non-performing" loans. The Japanese definition includes only loans for which

9 According to Nomura Research Institute (1994, page 9), " small and medium-sized companies that used to lead the recovery in capital outlays in past recoveries are showing no signs of moving... The current slump in capital investment is largely blameable on the weakness of demand, but when their fund demand for capital investment increases, if at all, in coming months, the reluctance of banking institutions to lend on account of the primary capital ratio imposed by the Bank for International Settlements (BIS) could become a serious roadblock hampering capital spending of small businesses." 
no interest has been received for six months or more and loans to legally bankrupt compranies. It does not include, however, restructured loans -- loans that have been rescheduled, often at below market rates, due to the borrower's inability to service the debt. If restructured loans were included, nonperforming loans would probably be at least twice as large.

A look at city bank resources for writing down problem loans suggests that some: banks will have difficulties addressing their loan-quality problems. First, as of March 1994, loan loss reserves covered (on average) only about 60 percent of the estimated losses on all bad loans. Second, banks could realize more gains on low book-value assets and use those gains to offset losses on bad loans. "Available" gains -- gains in excess of what is required to meet Basle capital standards -- would cover (on average) an additional 124 percent of possible loan losses. ${ }^{10} \mathrm{~A}$ final source of funds is shareholder equity. Available equity capital covers (on average) about 85 percent of the city tranks' estimated losses on bad loans. However, banks will likely be reluctant to tap into either unrealized gains or equity capital, since reductions would put further downward pressure on risk-based capital ratios, which are still relatively low by international standards.

While bank balance sheets clearly have deteriorated, evidence that this weakening has induced a significant tightening of credit supply has not been conclusive. The growth of bank credit has dropped sharply in recent years, as indicated in the top panel of Figure 3. However, this decline could also reflect reductions in loan demand as a result of weak consumption and investment or as a result of decreases in borrower's ability to qualify for loans due to falling collateral values. The middle panel of Figure 3 presents survey data on firms' judgements of the availability of loans. Notwithstanding a marked reduction in the availability of credit through early 1991, this measure did not drop much below its low point in the 1980-83 recession, and recently has improved to more normal levels.

10 This analysis ignores any depressing effect that an unanticipated en masse sale of securities would have on securities prices. 
On the other hand, the margin of interest rates on new loans over the cost of funds -- proxied by the Bank of Japan's official discount rate -- in the lower panel of Figure 3, has widened since 1990, suggesting that banks may indeed be restricting credit growth.

\section{A Macro Model with Financial Factors}

So far, we have outlined several ways in which financial factors can affect real activity (section Il). And, we have presented evidence that the financial positions of banks, households and firms weakened with sharp declines in equity and land prices in the early 1990s (section III), although they have not been severely compromised when compared to their pre-bubble levels. We now attempt to determ ine empirically whether financial factors play a role in generating or amplifying economic fluctuations in Japan and whether they were a contributing factor in the recent downturn.

In this section, we develop a small econometric model of the Japanese economy that includes a market for bank loans and a possible role for "financial factors." The model is similar to the one discussed in Bernanke and Blinder (1988). There are three types of economic agents in the model -banks, consumer/producers, and a monetary authority -- and there exist markets for goods and two financial assets (bank loans and equity capital). In all, there are seven structural equations that describe the behavior of agents in each market.

Although our model has many similarities to a traditional IS/LM model, there are several nontraditional features that allow for additional effects, such as those discussed in section II. First, we use movements in equity prices as a proxy for changes in the balance-sheet conditions of firms, households, and banks. Equity and land prices together are responsible for much of the variation in net wealth in Japan, and equity prices are highly correlated with land prices. ${ }^{11}$ Perhaps to a lesser extent, movements in equity prices may also serve to capture movements in collateral values, in the

11 Since quarterly observations on land prices and on the financial positions of Japanese banks, firms, and households are not available, we are forced to use equity prices as a proxy for both. 
incidence of excessive indebtedness among households and firms, in capital-asset ratios cf banks, and in non-performing loans.

Second, we used the negative of the TANKAN survey question on bank lending attitudes (which measures the perceived availability of loans) as a proxy for bank lending standarcs. As this survey question is specifically designed to measure borrowers' perceptions of non-price terms of bank credit, its use serves to further capture the effects of tight credit conditions. Finally, similar to the approach suggested by Bernanke and Blinder, we included the quantity of loans as a determinant of aggregate demand.

The model was estimated using data from 1970 though 1989, just prior to the sharp declines in asset prices and economic activity. For a number of the equations in the model, we present two different specifications -- one with a traditional set of explanatory variables, and another that includes our proxies for financial factors. Our estimation results indicate that the proxies have a slatistically significant role in explaining variations in bank loans, loan standards, and aggregate demand during the 1970-1989 period. The remainder of this section describes the data used in the model and presents the estimation results. The model will then be used in the next section to examine the role of financial factors in the 1990-1993 period.

\section{Data Description}

Using BOJ publications (1994a, 1994b), we constructed quarterly time-series from 1970:Q1 through 1993:Q4 for real GDP (Y), total real bank loans to domestic borrowers (L), average loan rates $\left(\mathrm{R}^{\mathrm{L}}\right)$, the BOJ's official discount rate $\left(\mathrm{R}^{\mathrm{O}}\right)$, the consumer price index $\left(\mathrm{P}^{\mathrm{Y}}\right)$, the TOPIX index of equity prices $\left(\mathrm{P}^{\mathrm{E}}\right)$, and the standards index $(\mathrm{S})$. Dickey-Fuller tests indicated that the loan rate, the official discount rate, loan standards, real loan growth, equity price inflation, and goods price inflation are stationary variables. Tests for the stationarity of GDP were inconclusive, although we treated GDP growth as stationary. Finally, cointegration tests on the full system suggested one cointegrating 
relationship between real bank loans and GDP; this relationship entered significantly in the aggregate demand equation only.

\section{Model Estimation}

The model is essentially an IS/LM model that has been augmented with a bank loan market, and it is similar to the model developed and discussed in Bernanke and Blinder (1988). Because of the recursive nature of the model, each equation was estimated using ordinary least-squares (OLS). ${ }^{12}$ These equations were estimated using data through 1989:Q4, just prior to the decline in equity prices, bank loans and economic activity. In general, each equation was estimated by regressing the LHS variable cin current and lagged values of RHS variables, as well as on lags of itself. A dynamic fit was obtained using a general-to-specific methodology that progressively eliminated variables with tstatistics less than two. In some cases, marginally-significant variables were retained if their inclusion was strongly suggested by theory. The remainder of this subsection outlines the econometric model.

Banks. Banks are assumed to provide intermediation services by securing equity capital and deposits and by offering loans to qualified applicants. Banks can affect the aggregate quantity of bank loans either by adjusting their price terms of credit -- the nominal loan rate -- or by changing their non-price terms of credit -- such as the qualifying standards on loans. The loan rate is affected primarily by the banks' cost of funds and a time-vary risk premium associated with the expected costs of borrower defaults or bankruptcies. Banks standards are set based on banks' views concerning the riskiness of bank lending. We estimated loan rate equations and loan standards equations with the following form (ignoring lags of all RHS and LHS variables):

12 Before omitting lags of some variables, our model can be viewed as an unrestricted structural VAR model with the following causal ordering: $\left(\Delta \mathrm{P}^{\mathrm{Y}}, \Delta \mathrm{Y}, \mathrm{R}^{\mathrm{O}}, \Delta \mathrm{P}^{\mathrm{E}}, \mathrm{R}^{\mathrm{L}}, \mathrm{S}, \Delta \mathrm{L}\right)$. 


$$
\begin{gathered}
R_{t}^{L}=R^{L}\left(L_{t-1}, R_{t}^{O}, \Delta Y_{t}, \Delta P_{t}^{E}\right)+\epsilon_{t}^{R L} \\
S_{t}=S\left(\Delta Y_{t}, \Delta P_{t}^{E}\right)+\epsilon_{t}^{S}
\end{gathered}
$$

where the official discount rate proxies for banks' short-term cost of funds; changes in equity prices capture changes in the expected costs (or risk) of bank lending; $\varepsilon^{\mathrm{LR}}$ represents an unexpected change (shock) to the lending rate; and $\varepsilon^{S}$ represents an unexpected change in loan standards. $W^{\prime} e$ expect banks' loan supply function is upward-sloping, and we expect that banks lower their loan rates and standards in response to increases in economic activity and in equity prices. The latter relationships are likely to hold, first, because a surge in economic activity or a stock market rally improves the cash-flow and balance-sheet positions of firms and households and generally signals a less risky lending environment for banks. Additionally, rising stock prices bolster the capital position of banks, which in Japan take significant equity positions, allowing them to make more, and possibly riskier, loans. ${ }^{13}$

Table la presents two specifications of equation (1) -- with and without proxies for financial factors. There are several important aspects of these estimates. First, we found that the supply curve is perfectly elastic with respect to loans (since the coefficient on bank loans was not significantly different from zero), and that loan rates are primarily determined by banks' short-term cost of funds (proxied here by the official discount rate). Second, changes in equity prices (see equaticn (la)) and aggregate income (not shown) have little explanatory power for loan rates. Finally, with regard to the specification without financial factors -- equation (1b) -- it can be seen that, in the long-run, banks raise their lending rates about 86 basis points in response to a 100 basis point increase in the discount rate -- $(.21+.35-.38) /(1-.79)=.86$. Still, banks adjust their lending rates rather slowly in the short-run.

13 Kim and Moreno (1994) used a VAR approach to identify a positive effect of stock prices on bank lending in Japan, although they did not distinguish between the effects on the supply versus the demand for loans. 
Banks can also affect the quantity of bank loans by changing the standards by which bank customers qualify for loans. Parameter estimates for two specifications of equation (2) are shown in Table $1 \mathrm{~b}$. Coefficients on equity prices enter significantly and with the expected signs, although in terms of either the $\mathbf{R}^{2}$ or the standard error of the regression, the variable provides only marginal explanatory power. As with loan rates, growth in aggregate income had no additional explanatory power. In summary, to the extent that banks respond to a riskier lending environment, they appear to do so by raising loan standards rather than by raising loan rates.

Consumer/producers. Consumer/producers wish to consume goods, which can be financed either with bank loans or by issuing equity. We assume that their demand curve for bank loans is:

$$
\Delta L_{t}=L\left(R R_{t}^{L}, S_{t}, \Delta Y_{t}, \Delta P_{t}^{E}\right)+\epsilon_{t}^{L D}
$$

where $\Delta \mathrm{L}$ denotes real loan growth; $R^{\mathrm{L}}=\mathrm{R}^{\mathrm{L}}-\Delta \mathrm{P}^{\mathrm{Y}}$ represents the ex-post real loan rate; $\Delta \mathrm{P}^{\mathrm{Y}}$ represents the change in goods prices (inflation); and $\varepsilon^{\mathrm{LD}}$ denotes a shock to loan demand. The real loan rate and economic growth represent the traditional determinants of loan demand. In addition, we allow an increase in loan standards to eliminate some loan applicants from consideration for a loan, thereby reducing loan demand. Conversely, an increase in asset prices improves collateral values and the balance-sheet positions of firms and households, which tends to create more qualified loan applicants and to increase loan demand. Of course, a positive correlation between loan growth and equity price inflation could indicate that stock market participants view the willingness of banks to extend new credit as a "buy" signal, if banks are assumed to have some inside information about the firms they' monitor.

Table 1c presents two specifications of equation (3). Proxies for financial factors enter significantly in the loan demand equation, although, as before, they do not substantially boost the $\mathrm{R}^{2}$ or reduce the standard error of the equation. There are several aspects of equation ( $3 a)$ that deserve mention. First, although an increase in the real loan rate decreases the demand for loans in the short- 
run, there is essentially no long-run effect of rates on loan demand. Second, an increase in loan standards (S) lowers loan growth, because the pool of eligible loan applicants decreases with an increase in loan standards. Third, an increase in aggregate demand also stimulates loan growth by stimulating either the transactions demand for credit (Bernanke and Blinder, 1988) or the investment demand for credit associated with expectations of further aggregate demand growth. Finally, an increase in equity prices raises loan demand. As discussed earlier, this proxy for financial factors could be reflecting the effects of improved collateral values and balance-sheet positions of borrowers.

The traditional determinants of aggregate demand are goods prices and the real interest rate. There are reasons, however, to believe that loan availability is also an important determinant of economic activity. As discussed by Bernanke (1983), Blinder and Stiglitz (1983), Bernanke and Blinder (1988) and others, if there is imperfect substitution between bank loans and other types of financing, then a contraction in bank loans would lower aggregate demand. ${ }^{14}$ We estimated aggregate demand equations of the following form:

$$
\Delta Y_{t}=Y\left(Y_{t-1}, L_{t-1}, \quad \Delta P_{t-1}^{Y}, \quad \Delta P_{t}^{E}\right)+\varepsilon_{t}^{Y}
$$

where $\varepsilon^{\mathrm{Y}}$ denotes a shock to aggregate demand. The optimal specification for this equation is shown as equation (4a) in Table 1d, along with a more-traditional specification (equation $4 b$ )). There is evidence of a cointegrating relationship between economic activity and loans in the aggregate demand equation. According to the error-correction coefficients in equation (4a), a one percent contraction in the supply of loans will decrease output about $6 / 10$ of one percent in the long run. In addition, increases in goods prices dampen aggregate demand, while increases in equity prices have positive effects on the demand for goods. Insofar as the level of loans already are controlled for in the

14 Hall and Thompson (1993) have argued that stronger assumptions are required; narnely, that the interest rate elasticity for borrowers with respect to bank loans must be larger than for other types
of financing. 
equation, the measured impact of equity prices on aggregate demand probably represents a traditional wealth effect -- that is, the impact on spending of an expansion of the lifetime budget constraint -rather than a financial effect associated with higher collateral values and borrowing opportunities.

Inflation is determined by a Phillips-curve relationship as follows:

$$
\begin{gathered}
\Delta P_{t}^{Y}=\underset{(-4.52)}{-112.4}+\underset{(4.63)}{.27} Y_{t-1}-\underset{(-4.90)}{.29} \text { TREND }_{t-1} \\
+\underset{(3.02)}{.31} \Delta P_{t-1}^{Y}+\underset{(4.00)}{.39} \Delta P_{t-2}^{Y}-\underset{(-1.78)}{.18} \Delta P_{t-4}^{Y}+\epsilon_{t}^{P Y} \\
R^{2}=.73, Q(20)=.64
\end{gathered}
$$

where TREND denotes a time-trend and $\varepsilon^{\mathrm{PY}}$ represents an inflation shock. According to equation (5), above-trend economic activity significantly raises inflationary pressures.

Mlonetary Authority. The monetary authority is assumed to control the official discount rate with the following reaction function:

$$
\begin{gathered}
R_{t}^{O}=\underset{(-3.91)}{-66.5}+\underset{(4.01)}{.16} Y_{t-1}-\underset{(-4.14)}{.17} \text { TREND }_{t-1} \\
-\underset{(-2.04)}{.15} \Delta Y_{t-1}+\underset{(10.94}{1.19} R_{t-1}^{O}-\underset{(-3.22)}{.34} R_{t-2}^{O}+\epsilon_{t}^{R O} \\
R^{2}=.94, Q(20)=.55
\end{gathered}
$$

where $\varepsilon^{R O}$ represents a unexpected change in the official discount rate. According to this reaction function, the monetary authority raises the discount rate when output is above trend, although this increase is extended over several periods.

Finally, the model is closed with a reduced-form description of the equity market: 


$$
\begin{gathered}
\Delta P_{t}^{E}=\underset{(2.42)}{554.3}-\underset{(-2.83)}{4.00} R_{t}^{O}+\underset{(2.64)}{3.45} R_{t-1}^{O} \\
+\underset{(1.95)}{1.82} \Delta Y_{t-2}-\underset{(-1.82)}{1.37} \Delta P_{t}^{Y}+\epsilon_{t}^{P E} \\
R^{2}=.26 Q(20)=.99
\end{gathered}
$$

where $\varepsilon^{\mathrm{PE}}$ denotes an unexpected shock to equity prices. This specification explains only about onequarter of the variance of stock price movements from 1970-89. Of the explained movernents, as theory predicts, an increase in the official discount rate has a small negative effect on stork prices, while increased economic growth boosts stock prices. Increases in inflation lower real stock prices, consistent with Feldstein's (1980) corporate-tax theory; see Fama and Schwert (1977), Solnik (1983), Ely and Robinson (1989), and Ammer (1994) for supporting empirical evidence.

\section{Financial Factors and the 1991-93 Recession}

In the previous section, we estimated several behavioral relationships for the Japanese economy using time-series data from 1970 through 1989. We found that proxies for financial factors entered with statistically-significant coefficients for the loan standards, loan demand, and aggregate demand equations, although these factors provided only marginal explanatory power over the estimation period. In this section, we use the model to investigate the extent to which financial factors have played a role in the recent recession in Japan.

We use the model in two ways. First, we test whether the model's equations remain stable during the 1990-1993 period. An unstable loan demand equation, for example, would indicate a structural shift in the usual relationship between the demand for bank loans and its determinants, including interest rates, aggregate income, loan standards, and the level of equity prices. Downward shifts in the loan demand equation could be attributable to balance-sheet problems of households or firms that are not captured by our model, although other factors could also be influencing loan 
demand. Similarly, unstable loan supply relationships, where banks have tightened loan rates or loan standards by unusual amounts, could be evidence (for example) that non-performing loan problems have resulted in unusually cautious banks.

Sizcond, we use the model to generate 1990-93 dynamic forecasts for all variables in the model. We then decompose the forecast errors for each variable in the model into those parts attributable to each structural error. This allows us to gauge directly the role played in Japan's recent recession by each financial factor in the model. We calculate, for example, the impact of the unexpected movements in stock prices that occurred in the early 1990s on the movements in bank loan rate spreads, loan standards, loan grówth, and aggregate demand.

\section{Model stability}

Table 2 examines the stability of the out-of-sample structural errors for the 1990:Q1 through 1993:Q4 period. The first column lists the possible sources of error, corresponding to the structural errors in equations (1) through (7). The next two columns show two simple measures of equation stability. The middle column lists the average error over the $90-93$ period. The results indicate that negative shocks to both loan demand and equity prices were on average significantly large over the 90-93 period, averaging about $1 / 2$ and 9 percent per quarter, respectively. Notably, average loan rate and loan :standard shocks are not statistically-different from zero.

The last column of the table lists the ratio of the variance of out-of-sample errors to the variance of the in-sample residuals. The loan demand and equity price errors are more volatile than their in-ssımple counterparts, indicating (as before) that these relationships behaved differently in the recessionary period. In addition, although the loan rate and aggregate demand errors are not biased away from zero, they were more volatile in the 1990 s than they were in previous periods.

Based on these results, it is evident that important variables may have been omitted from the structural relationship for loan demand and for equity prices -- equations (3a) and (7), respectively. It 
is difficult, however, to identify these variables. With regard to our behavioral equation for equity prices, many analysts have pointed to non-fundamental movements in the TOPIX during the late 1980s and early 1990s. ${ }^{15}$ With regard to our structural equation for loan demand, a possible explanation could be balance-sheet difficulties of consumers and firms not adequately captured by our econometric model. That is, an increased incidence of excessive indebtedness, not captured by the inclusion of equity prices as an explanatory variable, could account for the large loan demand errors seen in Table

2. However, the loan demand shocks could reflect any number of other factors, including, for example, a substitution of public for private sources of credit during the recession as increased resources were channeled to government financial institutions (OECD, 1993b).

\section{Model Forecasts and Decompositions}

Finally, we use the econometric model to gauge the economic importance of various structural shocks during the 1990-93 period. That is, we are interested in whether shocks to equity prices or shocks to loan supply variables had any effect on loan growth or economic activity during, the 1990-93 period relative to other sources of error. Accordingly, the model was used to calculate dynamic forecasts for each variable using only information available in 1989:Q4. These forecasts are presented in Figure 4, along with their actual values.

There are several interesting aspects of Figure 4 worth noting. First, both bank loans and GDP were significantly weaker over the forecast period than the model predicted, with the weakness in bank loans being especially pronounced. Second, loan rate spreads and loan standards ... shown in the middle panels -- appear to have been more restrictive than expected, suggesting evidence of a supply tightening by banks. Finally, the substantial fall in equity prices in the early 1990s (the lower left panel) was almost entirely unexpected. As a consequence, these shocks could well have had

15 See French and Poterba (1991) and Economic Planning Agency (1991, 1993). 
important effects on supply of loans -- with banks increasing loan rates and standards -- and on the demand for loans -- either through wealth effects that reduced economic activity or through reductions in loan ccllateral values.

These results appear to support the view that "financial factors" led, through various channels, to a tightening of credit by banks, a contraction in loan supply, and a consequent decline in economic activity. However, movements in the simulated values of the model variables do not necessarily reveal the underlying source of movement in these variables. For example, bank loan forecast errors could reflect shocks either to supply factors (loan rates and loan standards) or to demand factors (economic: activity, loan demand, and asset prices). In order to make any conclusive statements, these channels must be sorted out.

Table 3 summarizes the results of a decomposition of the dynamic forecast errors for each variable in 1991:Q4 and 1993:Q4. ${ }^{16}$ The dynamic forecast errors are listed in the second column of the table. For example, bank loans were 9 and 26 percent weaker in 1991:Q4 and 1993:Q4, respectively, than the model predicted. Similarly, economic activity (GDP) was 1 percent higher in 1991:Q4, but 8 percent weaker in 1993:Q4, than the model predicted.

The remaining columns of the table decompose each dynamic forecast error into possible sources of error. The important results of the decomposition exercise can be summarized as follows. First, we find only mixed support for the most obvious alternative explanation to the financial-factor hypothesis, that the downturn in bank loans and economic activity was caused by an autonomous contracticin in aggregate demand (perhaps stemming from the rise in the yen or from over-investment in the preceding period). Aggregate demand shocks appear to have worked toward raising growth in 1991:Q4 and to have had no effect on loans. By 1993:Q4, however, aggregate demand shocks

16 See Brunner and Kamin (1994) for a technical explanation of forecast error decomposition with strustural models. 
accounted for half of the shortfall in GDP below its predicted value, but only a small fraction of the shortfall in loans. These results suggest that aggregate demand shocks played no role in precipitating the recession, but may have deepened the downturn, once it got started. ${ }^{17}$ Even in the later phases of the recession, however, the shortfall in loan growth appears to have been reacting to much more than the decline in economic activity alone.

Second, loan supply shocks appear to have had played only a limited role, at most, in propagating the downturn. These shocks account for much of the increase in loan rate spreads and loan standards in the early part of the forecast period (1991:Q4). They also contributed to a small fraction of the shortfall in loans below predicted levels, and they exerted some downward pressure on economic activity during this period. In the later period (1993:Q4), loan supply shocks explain an equally small fraction of the shortfall in bank lending, and these shocks had essentially no effect on GDP. Hence, to the extent that loan supply shocks reflect Japanese banks' problems with capital and loan quality, the forecast decomposition results indicate that these problems had only a srnall effect on economic activity and that the existence of a "credit crunch" was limited to the early part of the forecast period.

Third, there is mixed evidence that balance-sheet problems affecting households and firms explain the recent contraction in bank lending and economic activity. On one hand, structural shocks to the loan demand and TOPIX equations appear to have had a significant effect on the exonomy in the 1990-93 period. Loan demand shocks are the primary factor underlying the deterioration in loan activity in both periods. They also appear to have trimmed economic activity by 2 percerit in 1993:Q4, although they had no effect on GDP in 1991:Q4. (As discussed above, unexplained shifts in the loan demand equation could reflect a deterioration of household and firm balance-sheet positions.)

17 The results for GDP are roughly consistent with Brunner and Kamin (1994). They found that asset prices shocks contributed early and investment demand shocks later to the Japanese recession. 
TOPIX shocks also contributed importantly to weak loan activity. Indeed, they represent the main factor exerting downward pressure on economic activity in 1991:Q4 -- all else equal, they would have depressed GDP by 4 percent. And, they are also estimated to have lowered GDP by 2 percent in 1993:Q4. To the extent that the effect of these shocks are proxying for changes in balance-sheet conditions: of households, firms, and banks, it appears that financial factors did have some effect on Japanese economic activity during the recent downturn.

On the other hand, these results must be interpreted with some caution. Shocks to the loan demand equation could easily reflect factors other than balance-sheet problems, such as a substitution of public for private credit. In addition, part of the effects of the TOPIX shocks on output appear to be coming from traditional wealth effects on aggregate demand, not from effects associated with weakened balance sheets and reduced bank intermediation. When we suppressed the traditional wealth-eflect channel in an alternative forecast, setting the coefficients on TOPIX in the aggregate demand equation to zero, the measured effects of asset price declines on economic activity were halved for 1991:Q4 and nearly eliminated for 1993:Q4. Finally, the effects of TOPIX shocks on loans and economic activity could also be reflecting other factors, such as a more pessimistic outlook for future corporate profits.

\section{Conclusion}

The primary objective of this paper was to take a closer look at the role of "financial factors" in Japan and to gauge their recent importance for the real economy. To that end, we estimated an econometric model of the Japanese economy that included a role for financial factors. We then used the model to explore whether the recent collapse of bank lending and economic activity can be traced in part to financial factors -- either because households and firms reduced their demand for loans as a result of balance-sheet difficulties stemming from asset price declines, or because banks tightened the supply of bank loans in response to increased expected costs of intermediation. 
Our results can be summarized as follows. First, we find that our proxies for financial factors entered significantly in behavioral equations for loan standards, loan demand, and aggregate demand, although these proxies provided only marginal explanatory power. Second, we found some evidence that an exogenous contraction in the supply of bank loans -- an unexpected increase in loan rate spreads and loan standards -- may have had a small negative influence on the level of bank loans and economic activity in the first year of the downturn. To the extent that these shocks can be associated with Japanese banks' problems with capital and loan quality, there may have bıen a small "credit crunch" in the early phases of the Japanese recession, although this factor appears not to have impeded economic activity later on.

Finally, there is some indirect econometric evidence that balance-sheet problems among households and firms caused the bank loans and economic activity to fall in the 1990-93 period. Most importantly, based on our model's simulation results, we find little support for the most obvious alternative explanation, that the downturn in bank loans was caused by the contraction in aggregate demand. Although about half of the decline in GDP during the latter phases of the recession can be attributed to aggregate demand shocks, these shocks had only a small influence on the quantity of bank loans.

Rather, a significant portion of the decline in loans and economic activity can be clirectly attributed to negative shocks to equity prices. While these price declines led banks to raisi loan rates and loan standards and borrowers to reduce their appetite for loans, part of the influence of asset price declines appears to be operating through traditional wealth effects. Negative shocks to the loan demand equation account for most of the remainder of the decline in bank loans and some of the decline in GDP. These shocks could reflect balance-sheet problems of households and firms that are not captured by our proxies -- which would be consistent with the negative effects of balarice-sheet difficulties - - although they could reflect many other, non-balance-sheet related factors as well. 


\section{References}

Ammer, John (1994), "Inflation, Inflation Risk, and Stock Returns," International Finance Discussion

Paper No. 464, Board of Governors of the Federal Reserve System, Washington, D.C.

Bank of Japan (1994a), Quarterly Bulletin, Volume 2, Number 4.

Bank of Japan (1994b), TANKAN (Short-Term Survey of Enterprises in Japan), August.

Bernanke. Ben S. (1983), "Nonmonetary Effects of the Financial Crisis in the Propagation of the Great Depression," American Economic Review, 73:257-76.

Bernanke., Ben S. (1990), "On the Predictive Power of Interest Rates and Interest Rate Spreads," New England Economic Review, Federal Reserve Bank of Boston, 51-68.

Bernanke. Ben S. (1993), "Credit in the Macroeconomy," Quarterly Review, Federal Reserve Bank of New York, 18:50-70.

Bernanke. Ben S. and Alan S. Blinder (1988), "Credit, Money, and Aggregate Demand," American Eronomic Review, AEA Papers and Proceedings, 78:435-39.

Bernanke, Ben S. and Alan S. Blinder (1992), "The Federal Funds Rate and the Channels of Monetary Transmission," American Economic Review, 82:901-21.

Bernanke, Ben S. and Cara Lown (1992), "The Credit Crunch," Brookings Papers on Economic Activity, 2:205-39.

Blinder, Alan S. and Joseph E. Stiglitz (1983), "Money, Credit Constraints and Economic Activity," American Economic Review, AEA Papers and Proceedings, 73:297-302.

Brunner, Allan D., and Steven B. Kamin (1994), "Determinants of the 1991-93 Recession in Japan: Evidence from a Structural Model of the Japanese Economy," International Finance Discussion Paper No. 479, Board of Governors of the Federal Reserve, Washington, D.C.

Diamond, Douglas (1984), "Financial Intermediation and Delegated Monitoring," Review of Eco nomic Studies, 51:393-414.

Economic Planning Agency (1991), Economic Survey of Japan 1990-1991: Conditions for Long Run Expansion and Japan's International Role, Tokyo.

Economic Planning Agency (1993), Economic Survey of Japan 1992-1993: What We Learned From the Bubble and Our Challenge to a New Development, Tokyo.

Economic Report of the President (1993), Washington, D.C. 
Ely, David P., and Kenneth J. Robinson (1989), "The Stock Market and Inflation: A Synthesis of the Theory and Evidence," Federal Reserve Bank of Dallas Economic Review Marcl1:17-29.

Fama, Eugene (1985), "What's Different about Banks?" Journal of Monetary Economics, 15:29-40.

Fama, Eugene, and William Schwert (1977), " Asset Returns and Inflation," Journal of Financial Eco nomics, 5:115-146.

Feldstein, Martin (1980), "Inflation and the Stock Market," American Economic Review, 70:839-847.

French, Kenneth R., and James R. Poterba (1991), "Were Japanese Stock Prices too High'?" Joumal of Financial Economies, Vol. 29, October.

Fries, Steven M. (1993), "Japanese Banks and the Asset Price 'Bubble'," IMF Working Paper, International Monetary Fund, Washington, D.C., WP/93/85.

Gertler, Mark (1983), "Financial Structure and Aggregate Economic Activity: An Overviє:w," Journal of Money, Banking and Credit, 20:559-88.

Gertler, Mark and Simon Gilchrist (1992), "Monetary Policy, Business Cycles, and the Behavior of Small Manufacturing Firms," working paper.

Gilchrist, Simon, Ben S. Bernanke, and Mark Gertler (1994), "The Financial Accelerator and the Flight to Quality," Finance and Economics Discussion Series paper, \#94-18, Board of Governors of the Federal Reserve System, Washington, DC.

Fazzari, Steven, R. Glenn Hubbard, and Bruce Petersen (1988), "Financing Constraints and Corporate Investment," Brookings Papers on Economic Activity, 1:141-195.

Hall, Brian J., and James D.C. Thompson (1993), "Are Bank Loans Really Special? Evidence on the Lending View," working paper, Harvard University, Department of Economics.

Hancock, Diana and James A. Wilcox (1993), "Has There Been a "Capital Crunch" in Barking? The Effects on Bank Lending of Real Estate Market Conditions and Bank Capital Shortfalls," Journal of Housing Economics, 3:31-50.

Hancock, Diana and James A. Wilcox (1995), "Bank Capital, Nonbank Finance, and Real Estate Activity," working paper, Board of Governors of the Federal Reserve System.

Hancock, Diana, Andrew J. Laing, and James A. Wilcox (1995), "Bank Capital Shocks: Dynamic Effects on Securities, Loans, and Capital," Journal of Banking and Finance, forthcoming. 
Hoshi, Takeo, Anil Kashyup, and David Scharfstein (1991), "Corporate Structure, Liquidity, and Irivestment," Quarterly Journal of Economics, 104:33-60.

Kim, Sun Bae and Ramon Moreno (1994), "Stock Prices and Bank Lending Behavior in Japan," Economic Review, No. 1, Federal Reserve Bank of San Francisco.

Kuttner, Kenneth (1992), "Monetary Policy and External Finance: The Implications of Short-Term Debt Flows," working paper, Federal Reserve Bank of Chicago.

Mieno, Yasushi (1993), "Current Monetary and Economic Conditions in Japan," Special Paper No. 231, Bank of Japan, Tokyo.

Mishkin, Frederic S. (1977), " What Depressed the Consumer? The Household Balance Sheet and the 1973-75 Recession," Brookings Papers on Economic Activity, 1:123-64.

Mishkin, Frederic S (1978), "The Household Balance Sheet and the Great Depression," Journal of Economic History, 38:918-37.

Nomura Fiesearch Institute (1994), Quarterly Economic Review, Vol.24, No. 4.

OECD (1993a), "Implications of Financial Stress for Economic Recovery," in $O E C D$ ECONOMIC OUTLOOK, 54, December.

OECD (1993b), OECD Economic Surveys 1992-1993: Japan, Paris.

Oliner, Stephen, and Glenn Rudebusch (1994), "Is There a Broad Credit Channel to Monetary Policy," working paper, Board of Governors of the Federal Reserve System.

Peek, Joe and Eric Rosengren (1992), "The Capital Crunch in New England," New England Economic Review, Federal Reserve Bank of Boston, 21-31.

Schinasi, 'Jary J. and Monica Hargraves (1992), "Asset Price Deflation, Balance Sheet Adjustment, and Financial Fragility," World Economic Outlook, International Monetary Fund, Washington, D.C., October, 57-68.

Schinasi, Gary J. and Monica Hargraves (1993), "'Boom and Bust' in Asset Markets in the 1980s: Causes and Consequences," in International Monetary Fund, Staff Studies for the World Econcmic Outlook, Washington, D.C., December.

Sharpe, Steven A. (1995), "Bank Capitalization, Regulation, and the Credit Crunch," Finance and Economics Discussion Series \#95-20, Board of Governors of the Federal Reserve System.

Solnik, Bruno (1983), "The Relation Between Stock Prices and Inflationary Expectations: The International Evidence," Journal of Finance, 38:35-48. 
Syron, Richard (1991), "Are We Experiencing a Credit Crunch?" New England Economic Review, Federal Reserve Bank of Boston, 3-10.

Takeda, Masahiko and Phillip Turner (1992), "The Liberalization of Japan's Financial Markets: Some Major Themes," BIS Economic Papers, Bank for International Settlements, Basle: Switzerland, \#34.

Williamson, Stephen (1986), "Costly Monitoring, Financial Intermediation, and Equilibrium Credit Rationing," Journal of Monetary Economics, 18:159-79. 
Figure 1. Balance Sheet Positions of Households

(all variables are expressed as ratios)
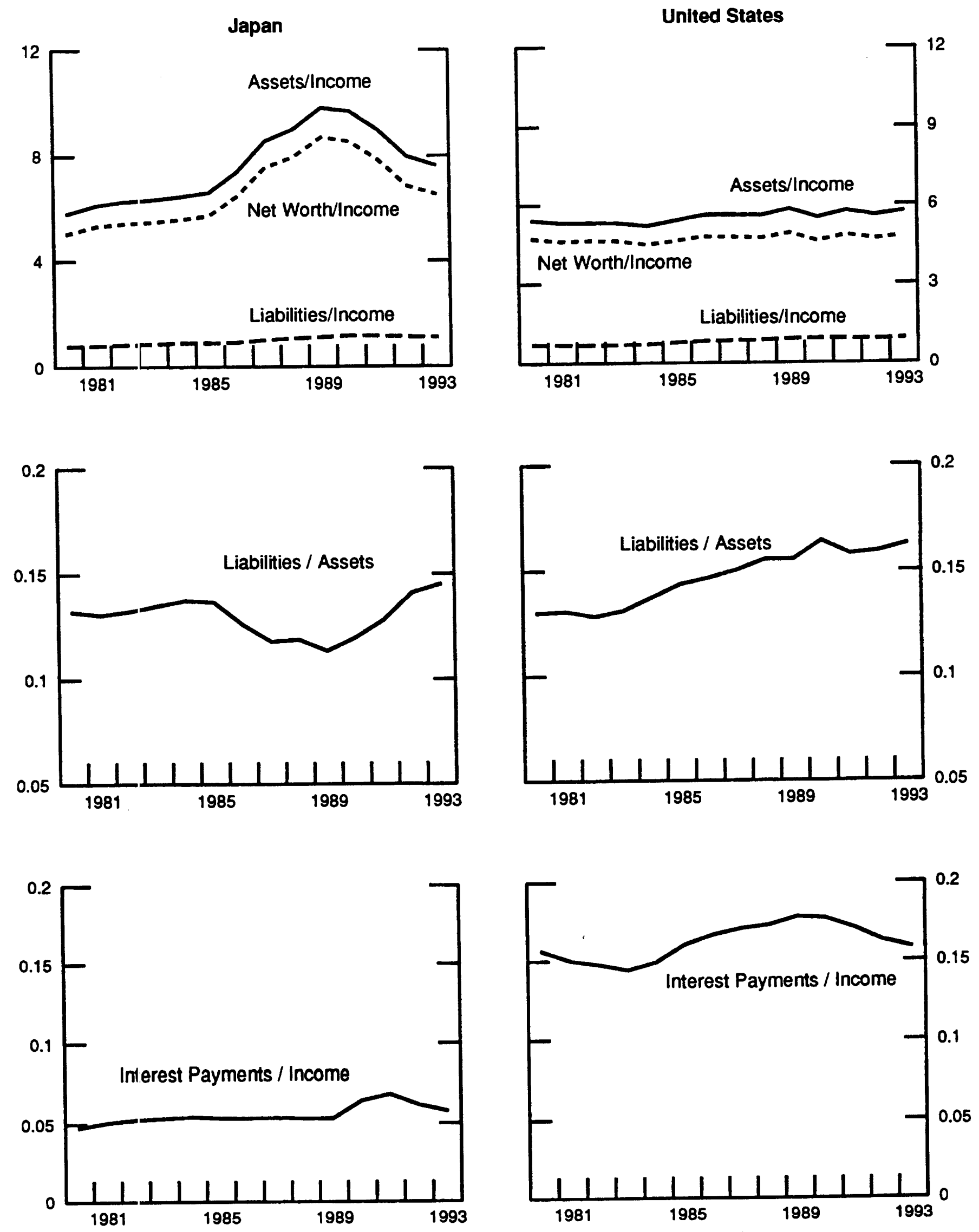

Income is I rousehold disposable income.

Source: Ecionomic Planning Agency, Annual Report on Nationad Accounts. of Commerce, National Income and Product Accounts. 
Figure 2. Balance Sheet Positions of Nonfinancial Corporations

(all variables are expressed as ratios)

Japan
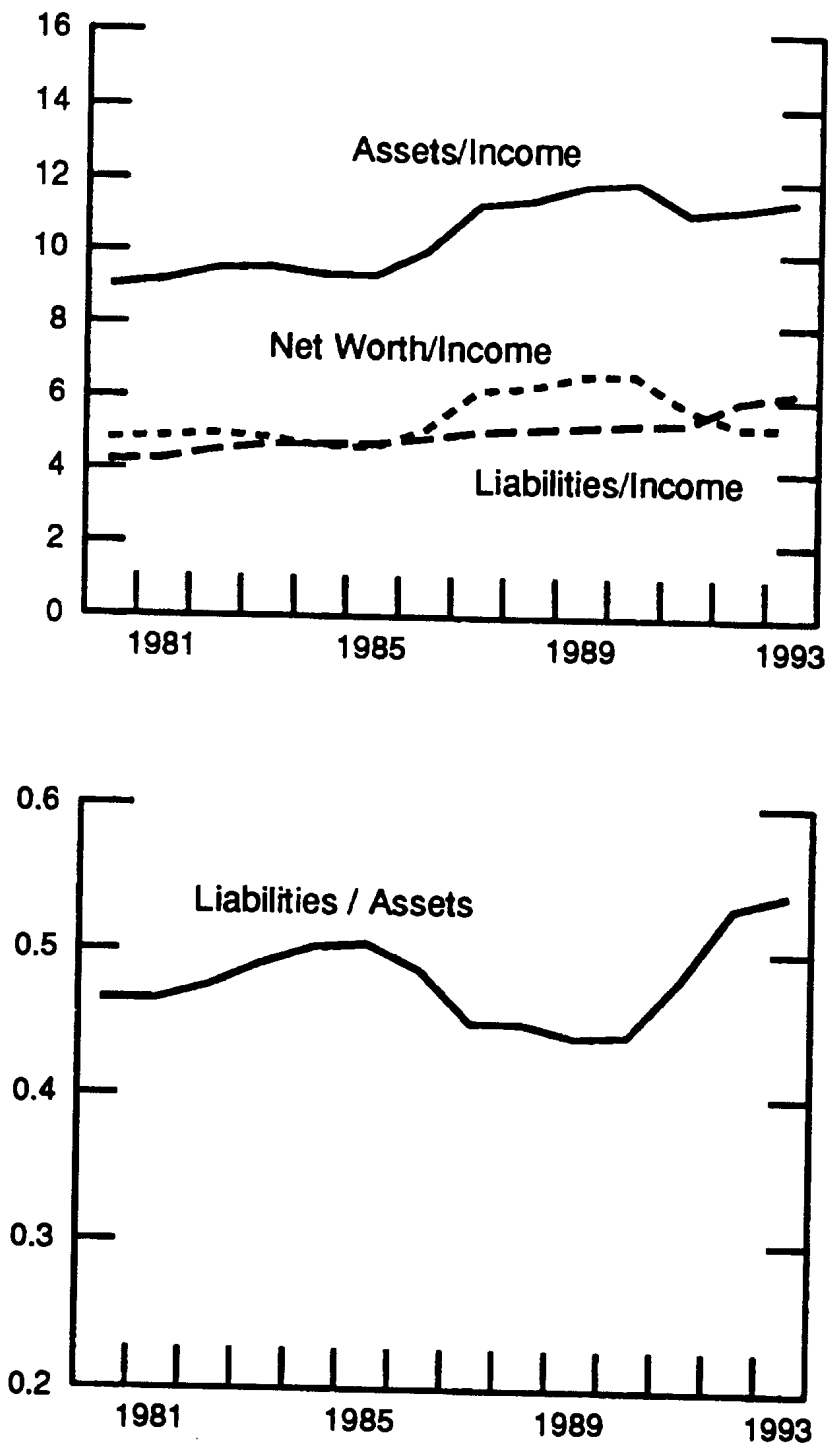
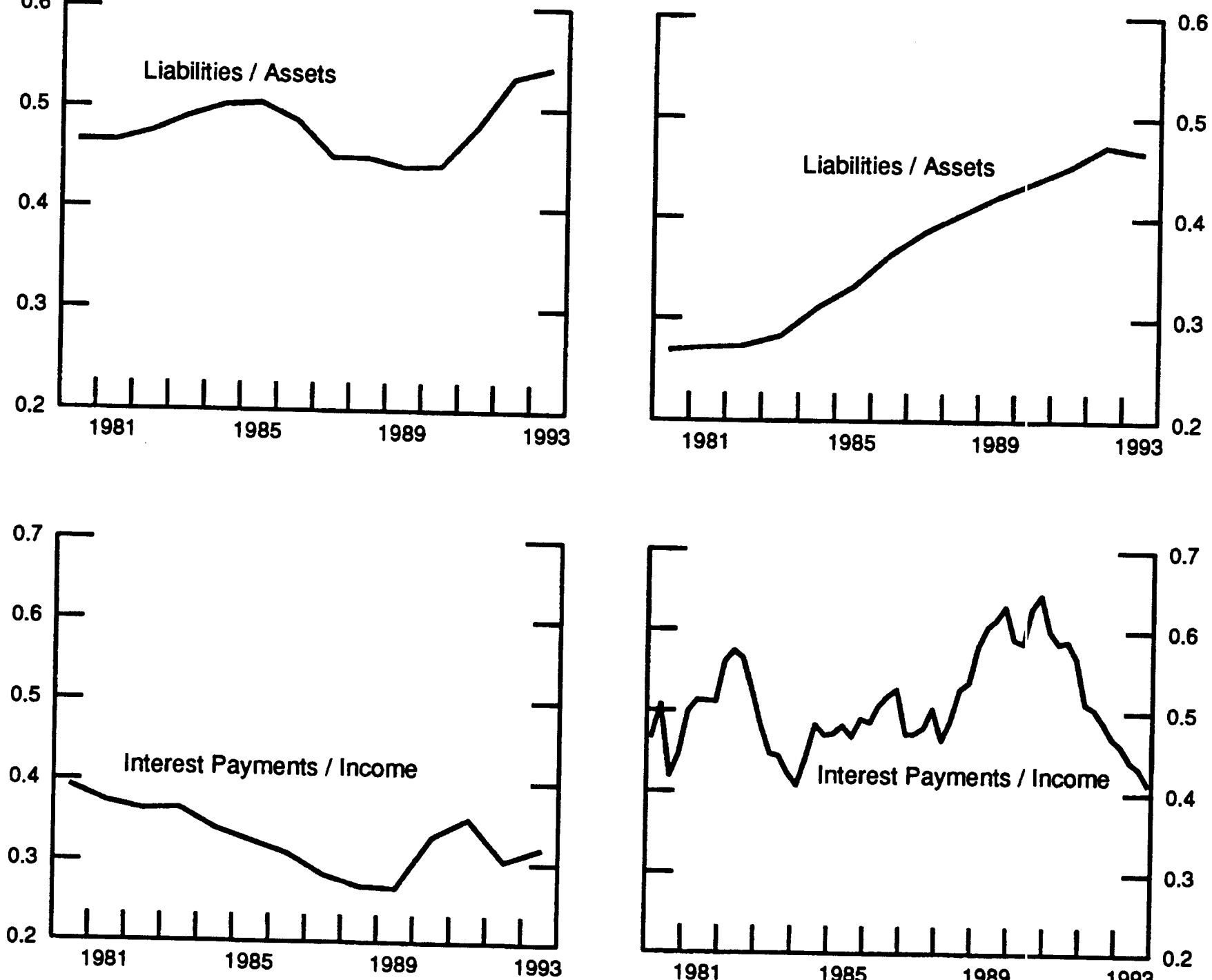

Income is profits plus depreciation of fixed capital. Source: Economic Planning Agency, Annual Report on National Accounts.

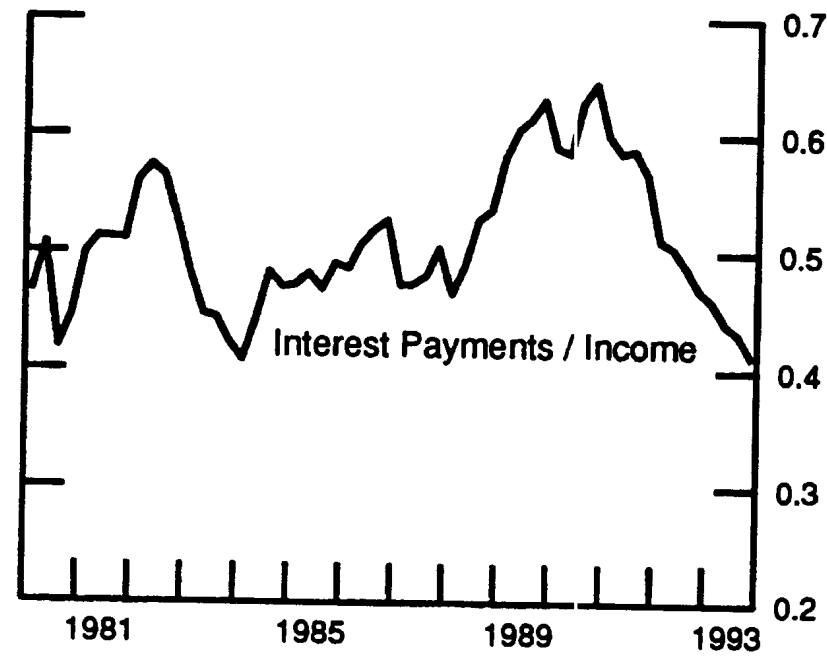

Income equals profits before tax plus capital consumption adjustment, depreciation, and inventory valustion adjustment. Source: Federal Reserve Board, Flow of Funds Accounts; Department of Commerce. National Income and Product 4ccounts. 
Figure 3. Indicators of Credit Availability

Japanese Bank Loans and GDP

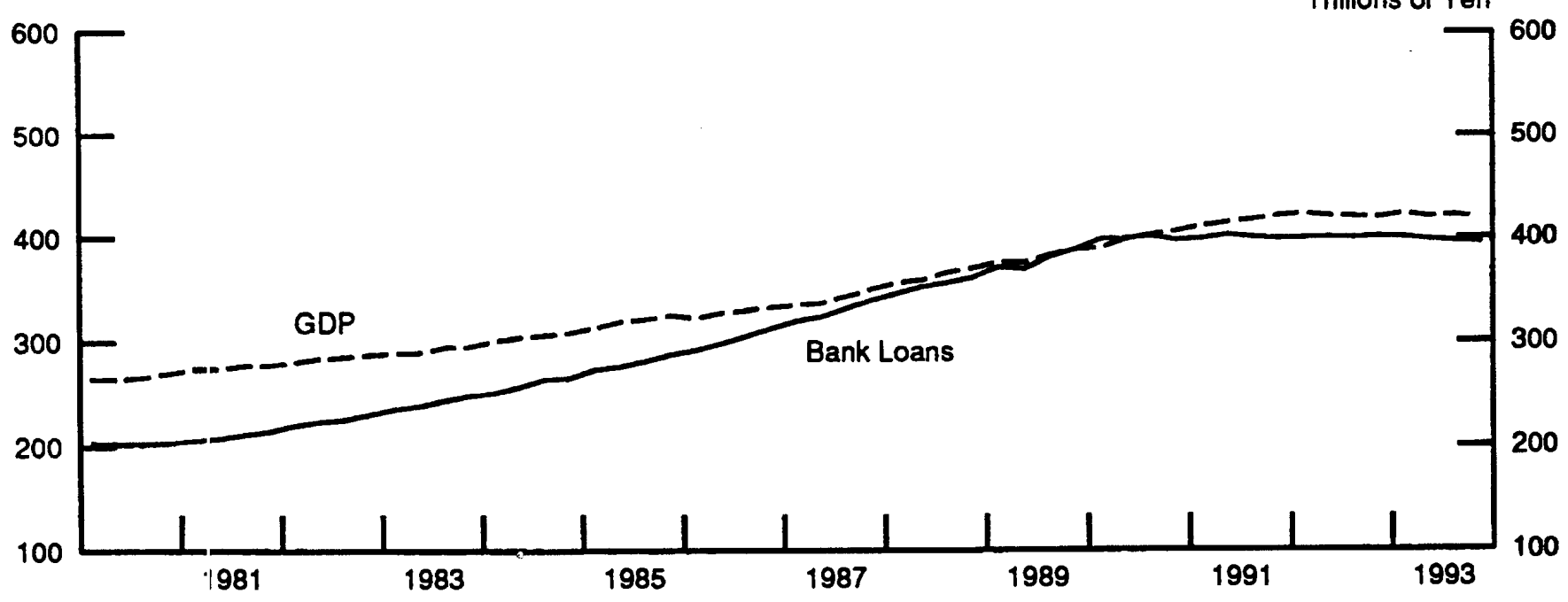

Firms' Judgment of Loan Availability

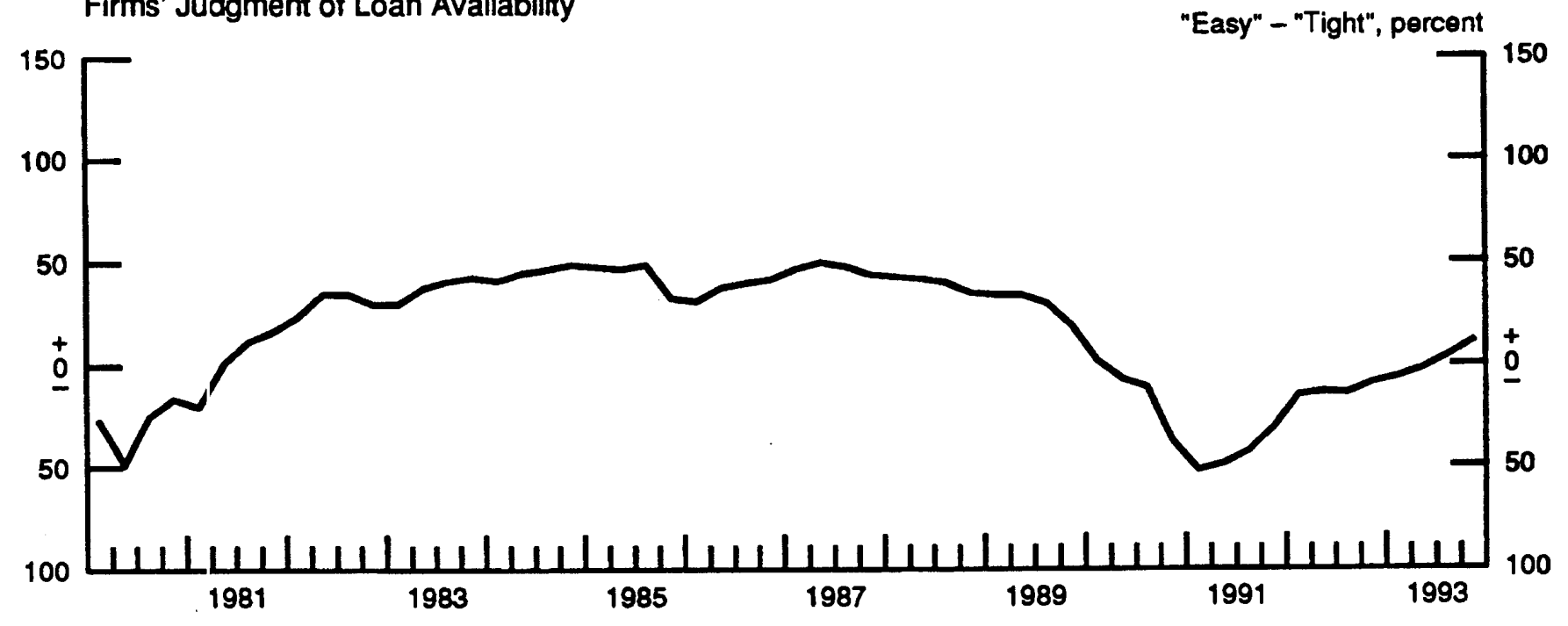

Margin of New Loan Rate over Cost of Funds

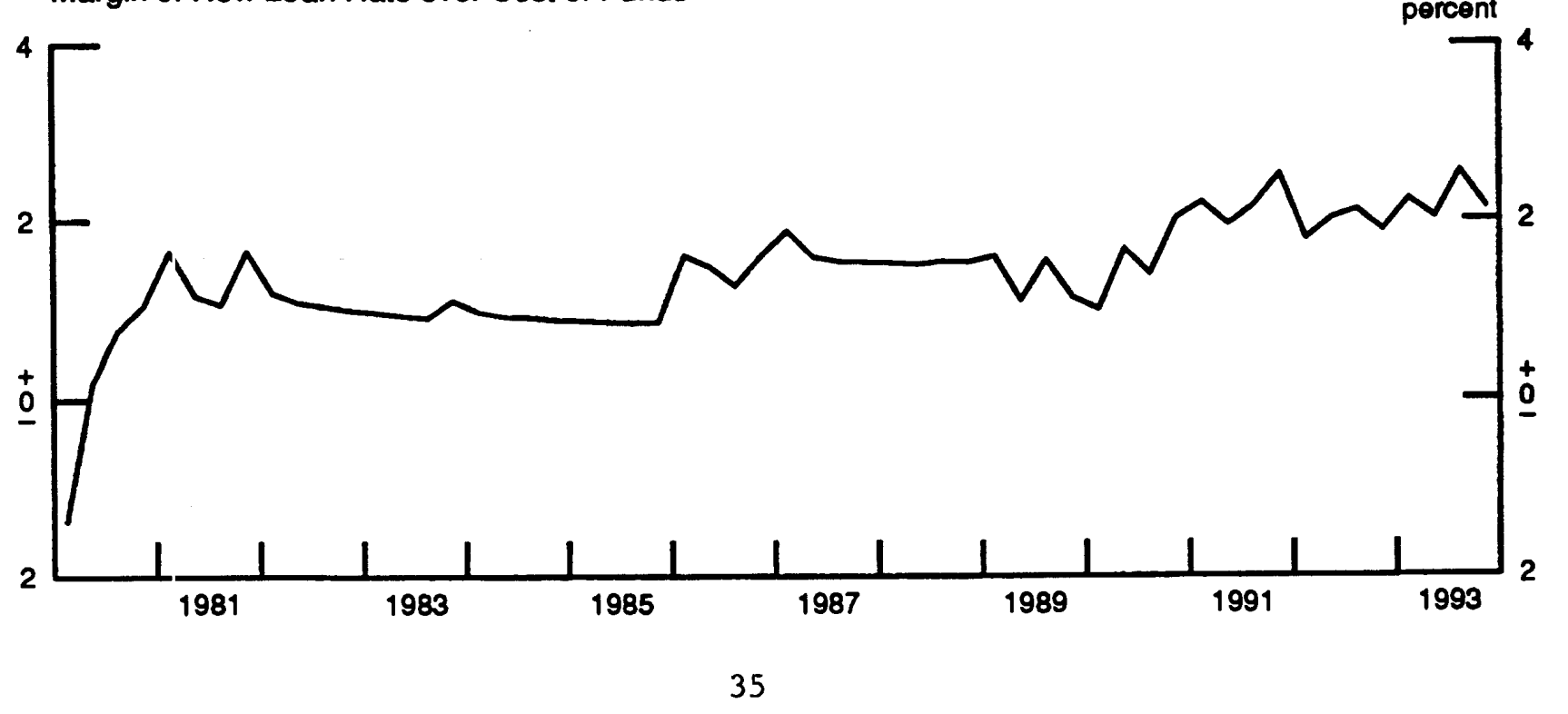


Figure 4. Dynamic Forecasts of Model Variables

Real Bank Loans

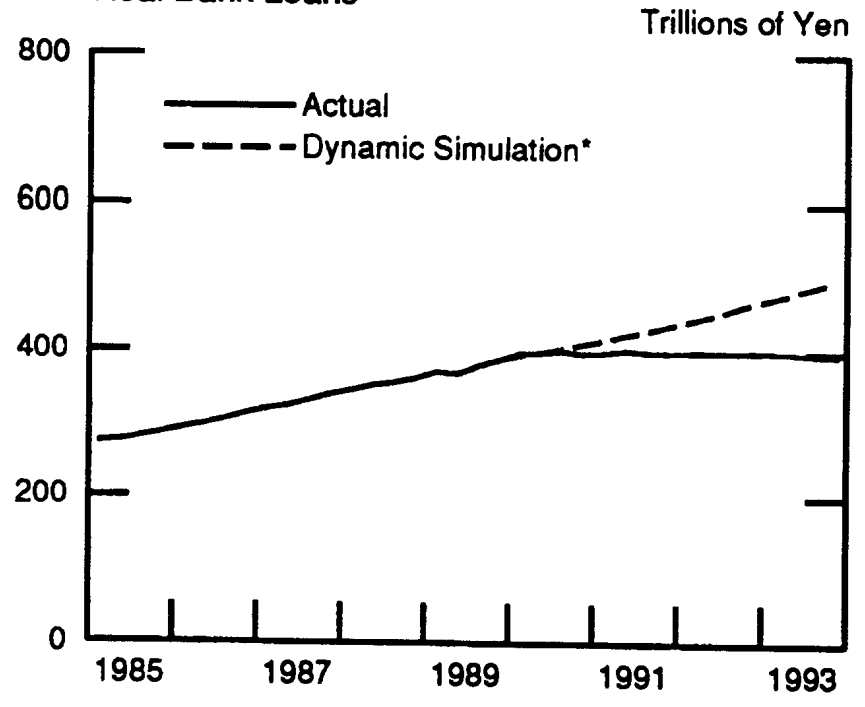

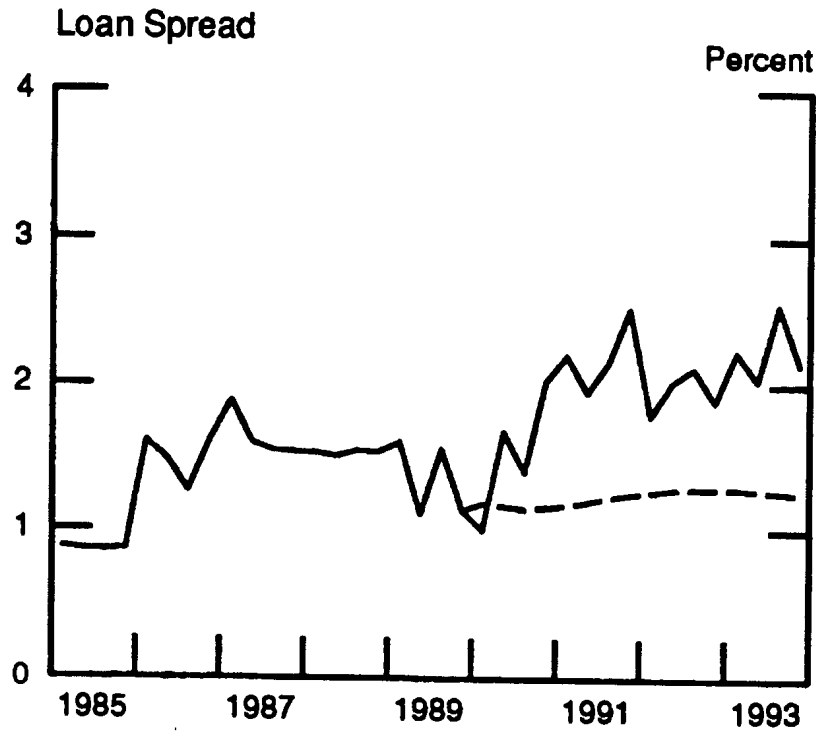

Real Topix

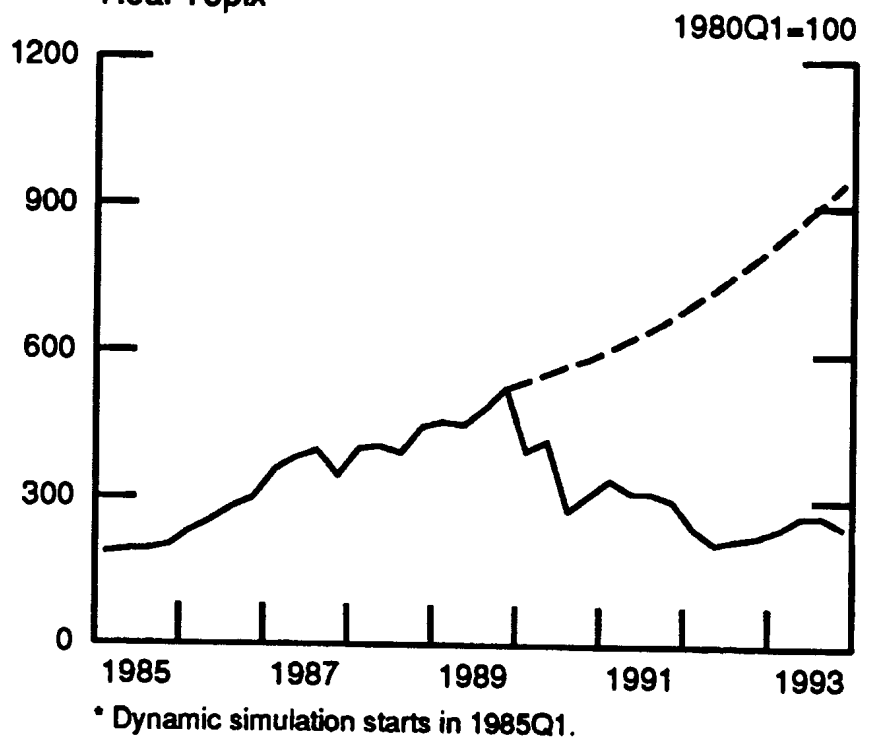

Real GDP

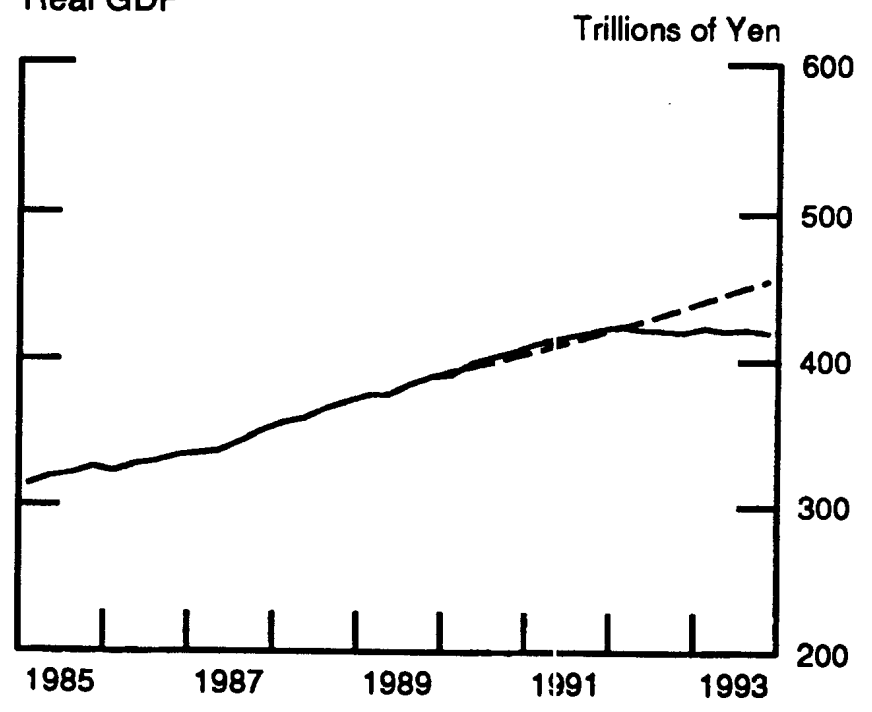

Loan Standards

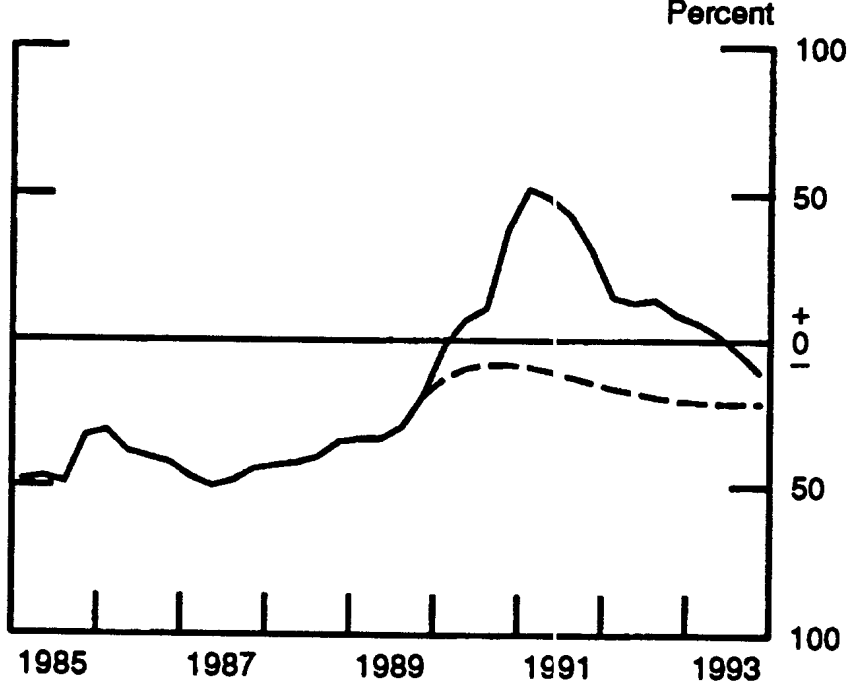

Inflation

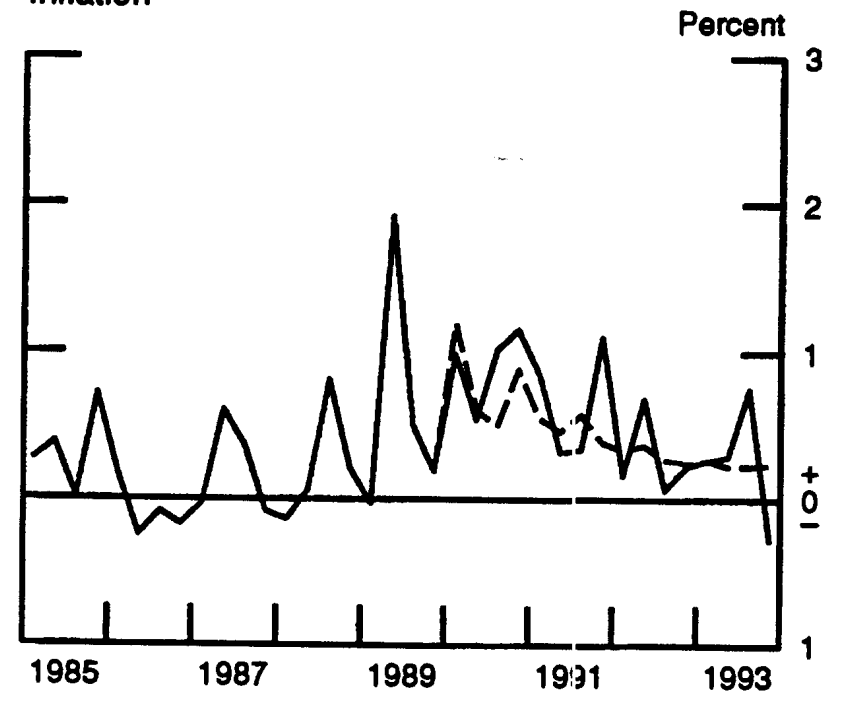


Table la. Parameter Estimates for Equation (1) -- Loan Supply Equation (LHS Variable is $\mathrm{R}_{\mathfrak{t}}^{\mathrm{L}}$ )

\begin{tabular}{|c|c|c|}
\hline RHS Variable & $\begin{array}{c}\text { With "Financial Factors" } \\
\text { Equation (la) }\end{array}$ & $\begin{array}{c}\text { Without "Financial Factors" } \\
\text { Equation ( } 1 \mathrm{~b})\end{array}$ \\
\hline constant & $\begin{array}{c}.40 \\
(3.1)\end{array}$ & $\begin{array}{c}.41 \\
(3.1)\end{array}$ \\
\hline$R_{t}^{O}$ & $\begin{array}{c}.23 \\
(5.1)\end{array}$ & $\begin{array}{c}.21 \\
(4.4)\end{array}$ \\
\hline $\mathrm{R}_{\mathrm{t}-1}^{\mathrm{O}}$ & $\begin{array}{c}.32 \\
(4.4)\end{array}$ & $\begin{array}{c}.35 \\
(4.5)\end{array}$ \\
\hline $\mathrm{R}_{\mathrm{t}-2}^{\mathrm{O}}$ & $\begin{array}{l}-.37 \\
(-7.5)\end{array}$ & $\begin{array}{c}-.38 \\
(-7.6)\end{array}$ \\
\hline$R_{t-1}^{L}$ & $\begin{array}{c}.80 \\
(12.1)\end{array}$ & $\begin{array}{c}.79 \\
(11.8)\end{array}$ \\
\hline$\Delta P_{t}^{E}$ & $\begin{array}{l}.003 \\
(1.4)\end{array}$ & \\
\hline$\Delta \mathrm{P}_{\mathrm{t}-1}^{\mathrm{E}}$ & $\begin{array}{l}-.004 \\
(-1.4)\end{array}$ & \\
\hline $\mathbf{R}^{2}$ & .99 & .99 \\
\hline SE & .147 & .148 \\
\hline p-value for $Q(20)$ & .73 & .84 \\
\hline
\end{tabular}

Note: T-s atistics are in parentheses and have been corrected for the possible presence of heteroskedasticity. 
Table 1b. Parameter Estimates for Equation (2) -- Loan Standards Equatior (LHS Variable is $S_{t}$ )

\begin{tabular}{ccc}
\hline \hline RHS Variable & $\begin{array}{c}\text { With "Financial Factors" } \\
\text { Equation (2a) }\end{array}$ & $\begin{array}{c}\text { Without "Financial Factors" } \\
\text { Equation (2b) }\end{array}$ \\
\hline constant & -.17 & -1.26 \\
& $(-0.1)$ & $(-0.9)$ \\
$\mathrm{S}_{\mathrm{t}-1}$ & 1.48 & 1.58 \\
& $(13.1)$ & $(13.4)$ \\
$\mathrm{S}_{\mathrm{t}-2}$ & -.62 & -.67 \\
& $(-5.6)$ & $(-5.6)$ \\
$\Delta \mathrm{P}_{\mathrm{t}}^{\mathrm{E}}$ & -.32 & \\
& $(-2.3)$ & \\
$\Delta \mathrm{P}_{\mathrm{t}-1}^{\mathrm{E}}$ & -.32 & .72 \\
& $(-2.3)$ & \\
$\mathrm{p}-\mathrm{value}$ for Q(20) & & \\
$\mathrm{SE}$ & & \\
$\mathrm{R}^{2}$ & .95 & 11.1 \\
\hline
\end{tabular}

Note: T-statistics are in parentheses and have been corrected for the possible presence of heteroskedasticity. 
Table Ic. Parameter Estimates for Equation (3) -- Loan Demand Equation (LHS Variable is $\Delta \mathrm{L}_{\mathrm{t}}$ )

\begin{tabular}{|c|c|c|}
\hline RHS Variable & $\begin{array}{c}\text { With "Financial Factors" } \\
\text { Equation (3a) }\end{array}$ & $\begin{array}{c}\text { Without "Financial Factors" } \\
\text { Equation }(3 b)\end{array}$ \\
\hline constant & $\begin{array}{l}-1.30 \\
(-2.4)\end{array}$ & $\begin{array}{l}-2.42 \\
(-4.6)\end{array}$ \\
\hline$R^{2}{ }_{t}^{L}$ & $\begin{array}{l}-.19 \\
(-1.8)\end{array}$ & $\begin{array}{l}-.08 \\
(-1.7)\end{array}$ \\
\hline$R R_{t-1}^{L}$ & $\left(\begin{array}{c}77 \\
(8.2)\end{array}\right.$ & $\begin{array}{l}.88 \\
(9.4)\end{array}$ \\
\hline$R R_{t-2}^{L}$ & $\begin{array}{l}-.35 \\
(-3.0)\end{array}$ & $\begin{array}{l}-.36 \\
(-2.8)\end{array}$ \\
\hline$\Delta Y_{t}$ & $\begin{array}{c}.23 \\
(2.3)\end{array}$ & $\begin{array}{l}.22 \\
(1.9)\end{array}$ \\
\hline$\Delta \mathrm{L}_{\mathrm{t}-1}$ & $\begin{array}{l}.24 \\
(2.4)\end{array}$ & $\begin{array}{l}.35 \\
(3.4)\end{array}$ \\
\hline$\Delta \mathrm{L}_{\mathrm{t}-2}$ & $\begin{array}{l}.25 \\
(4.3)\end{array}$ & $\begin{array}{l}.30 \\
(4.7)\end{array}$ \\
\hline$\Delta \mathrm{L}_{\mathrm{t}-3}$ & $\begin{array}{c}31 \\
(3.7)\end{array}$ & $\begin{array}{c}.29 \\
(3.1)\end{array}$ \\
\hline$S_{t}$ & $\begin{array}{l}-.01 \\
(-3.3)\end{array}$ & \\
\hline$S_{t-1}$ & $\begin{array}{c}.01 \\
(3.3)\end{array}$ & \\
\hline$\Delta \mathrm{P}_{\mathrm{t}}^{\mathrm{E}}$ & $\begin{array}{l}.03 \\
(2.8)\end{array}$ & \\
\hline $\mathrm{R}^{2}$ & .82 & .78 \\
\hline SE & .697 & .767 \\
\hline p-value: for $Q(20)$ & .98 & .93 \\
\hline
\end{tabular}

Note: T-statistics are in parentheses and have been corrected for the possible presence of heteroskedasticity. 
Table 1d. Parameter Estimates for Equation (4) -- Aggregate Demand Equation (LHS Variable is $\Delta \mathrm{Y}_{\mathrm{t}}$ )

\begin{tabular}{|c|c|c|}
\hline RHS Variable & $\begin{array}{l}\text { With "Financial Factors" } \\
\text { Equation (4a) }\end{array}$ & $\begin{array}{c}\text { Without "Financial Factors" } \\
\text { Equation }(4 \mathrm{~b})\end{array}$ \\
\hline constant & $\begin{array}{l}5.77 \\
(1.9)\end{array}$ & $\begin{array}{l}1.34 \\
(4.7)\end{array}$ \\
\hline$\Delta P^{Y}{ }_{t}$ & $\begin{array}{l}-.24 \\
(-2.1)\end{array}$ & $\begin{array}{l}-.25 \\
(-2.0)\end{array}$ \\
\hline$\Delta P_{t-1}^{Y}$ & $\begin{array}{c}-.14 \\
(-2.2)\end{array}$ & \\
\hline$\Delta \mathrm{P}_{\mathrm{t}-2}^{\mathrm{Y}}$ & $\begin{array}{c}.14 \\
(2.2)\end{array}$ & $\begin{array}{c}.26 \\
(3.0)\end{array}$ \\
\hline$R R_{t-1}^{O}$ & & $\begin{array}{c}-.12 \\
(-2.1)\end{array}$ \\
\hline$\Delta \mathrm{P}_{\mathrm{t}-1}^{\mathrm{E}}$ & $\begin{array}{c}.03 \\
(2.4)\end{array}$ & $\begin{array}{c}.04 \\
(3.1)\end{array}$ \\
\hline$\Delta \mathrm{P}_{\mathrm{t}-2}^{\mathrm{E}}$ & $\begin{array}{c}.02 \\
(1.9)\end{array}$ & $\begin{array}{c}.03 \\
(2.9)\end{array}$ \\
\hline$Y_{t-1}$ & $\begin{array}{l}-.04 \\
(-3.4)\end{array}$ & \\
\hline$L_{t-1}$ & $\begin{array}{c}.03 \\
(2.5)\end{array}$ & \\
\hline $\mathrm{R}^{2}$ & .35 & .28 \\
\hline SE & .684 & .716 \\
\hline$p$-value for $Q(20)$ & .50 & .60 \\
\hline
\end{tabular}

Note: T-statistics are in parentheses and have been corrected for the possible presence of heteroskedasticity. 
Table 2. Tests for Out-of-Sample Stability of Structural Equations

\begin{tabular}{lcc}
\hline \hline Equation & Average Error & Ratio of Variances \\
\hline & & \\
(1b) -- Loan Rate & .09 & $3.87^{* * *}$ \\
(2a) -- Loan Standards & $2.12^{* *}$ & $.32^{* *}$ \\
(3a) -- Loan Demand & $-.49^{* *}$ & $2.45^{* * *}$ \\
(4a) -- Aggregate Demand & $-.05^{* * *}$ \\
(5) -- Inflation & $.33^{*}$ & $2.58^{* * *}$ \\
(6) -- Discount Rate & $-.08^{* *}$ & $1.33^{* *}$ \\
(7) -- Equity Prices & $-8.82^{* *}$ & $6.72^{* * *}$ \\
\hline \hline
\end{tabular}

Notes: The average error is the mean of the structural errors for the 1990-1993 period. The ratio of variances is the ratio of the out-of-sample errors to the variance of in-sample residuals. Significance levels for 10,5 , and 1 percent are indicated by ${ }^{*},{ }^{* *}$ and ${ }^{* * *}$. 


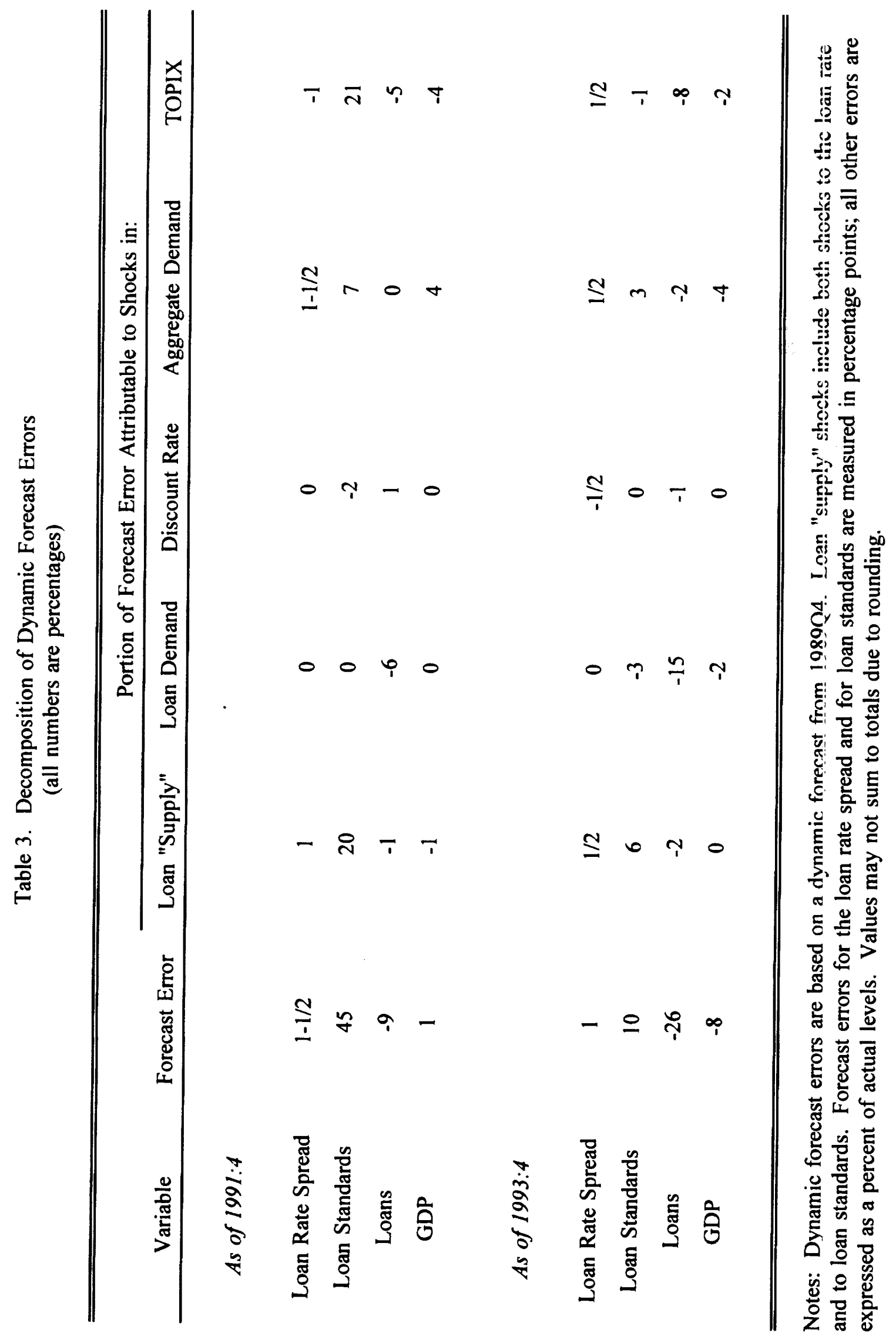




\section{International Finance Discussion Papers}

IFDP

Number

Titles

Author(s)

1995

513 Bank Lending and Economic Activity in Japan:

Did "Financial Factors" Contribute to the Recent

Downturn?

512 Evidence on Nominal Wage Rigidity From a Panel

of U.S. Manufacturing Industries

511 Do Taxes Matter for Long-Run Growth?: Harberger's Superneutrality Conjecture

Allan D. Brunner

Steven B. Kamin

Vivek Ghosal

Prakash Loungani

Enrique G. Mendoza

Gian Maria Milesi-Ferretti

Patrick Asea

510 Options, Sunspots, and the Creation of Uncertainty

David Bowman

Jon Faust

509 Hysteresis in a Simple Model of Currency Substitution

Martin Uribe

508 Import Prices and the Competing Goods Effect

Phillip Swagel

507 Supply-side Economics in a Global Economy

Enrique G. Mendoza

Linda L. Tesar

506 The Lucas Critique In Practice: Theory Without Measurement

Neil R. Ericsson

John S. Irons

505 Real Exchange Rate Targeting and Macroeconomic Instability

Martin Uribe

504 Inferences from Parametric and Non-Parametric Covariance Matrix Estimation Procedures

Wouter J. Den Haan

Andrew T. Levin

503 Exchange-Rate Based Inflation Stabilization: The Initial Real Effects of Credible Plans

Martin Uribe

502 Strategic Returns to International

Diversification: An Application to the Equity

Markets of Europe, Japan, and North America

John Ammer

Jianping Mei

501 Real Exchange Rate Movements in High Inflation

John H. Rogers

Countries

Ping Wang

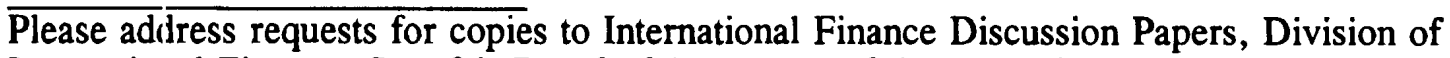
International Finance, Stop 24, Board of Governors of the Federal Reserve System, Washington, DC 20551. 


\section{International Finance Discussion Papers}

IFDP

Number
Titles

$\underline{1995}$

$500 \quad$ Political Competition, Casual Relations Between

Taxes and Spending, and Their Influence on

Government Size: Evidence From State-Level Data

499 International Stock Price Spillovers and Market

Liberalization: Evidence From Korea, Japan, and the United States

$498 \quad$ How Wide is the Border?

497

496 Saving-Investment Associations and Capital Mobility On the Evidence from Japanese Regional Data

495 Convertibility Risk, Default Risk, and the Mexdollar Anomaly

494 Government Budget Deficits and Trade Deficits Are Present-Value Constraints Satisfied in Long-Term Data?

Real Shocks and Real Exchange Rates in Really Long-Term Data

\section{4}

492 Loss Aversion in a Consumption/Savings Model

491 Terms-of-Trade Uncertainty and Economic Growth: Are Risk Indicators Significant in Growth Regressions

490 Politics, Economics, and Investment: Explaining Plant and Equipment Spending by U.S. Direct Investors in Argentina, Brazil, and Mexico

489 On The Dynamic Properties of Asymmetric Models of Real GNP

488 A distributed block approach to solving near-block-diagonal systems with an application to a large macroeconometric model
Author(s!

Diane Lim Rogers

John H. Rogers

Sang W. Kim

John H. Rogers

Charles Engle

John H. Rogers

David Bowman

Robert Dekle

John H. Rogers

Shaghil Atımed

John H. Rıgers

John H. Rogers

David Bow'man

Deborah Mlinehart

Matthew Rabin

Enrique G. Mendoza

Guy V.G. Stevens

Allan D. Brunner

Jon Faust

Ralph Tryon 